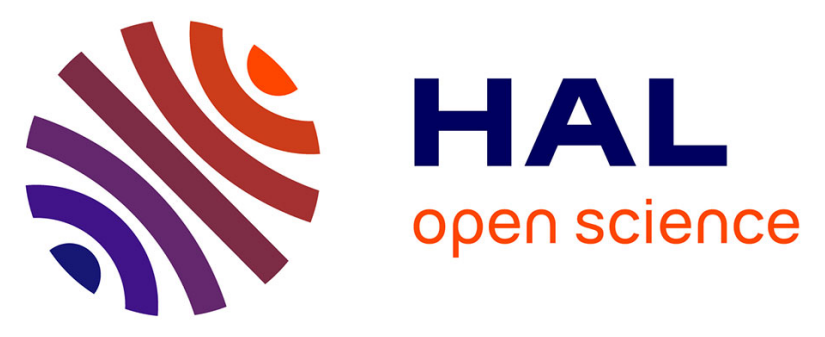

\title{
Evidence of the impact of urbanization on the hydrological regime of a medium-sized periurban catchment in France
}

Isabelle Braud, Pascal Breil, F. Thollet, M. Lagouy, F. Branger, C.

Jacqueminet, S. Kermadi, K. Michel

\section{To cite this version:}

Isabelle Braud, Pascal Breil, F. Thollet, M. Lagouy, F. Branger, et al.. Evidence of the impact of urbanization on the hydrological regime of a medium-sized periurban catchment in France. Journal of Hydrology, 2013, 485, pp.5-23. 10.1016/j.jhydrol.2012.04.049 ujm-01620543

\section{HAL Id: ujm-01620543}

\section{https://hal-ujm.archives-ouvertes.fr/ujm-01620543}

Submitted on 25 Oct 2017

HAL is a multi-disciplinary open access archive for the deposit and dissemination of scientific research documents, whether they are published or not. The documents may come from teaching and research institutions in France or abroad, or from public or private research centers.
L'archive ouverte pluridisciplinaire HAL, est destinée au dépôt et à la diffusion de documents scientifiques de niveau recherche, publiés ou non, émanant des établissements d'enseignement et de recherche français ou étrangers, des laboratoires publics ou privés. 


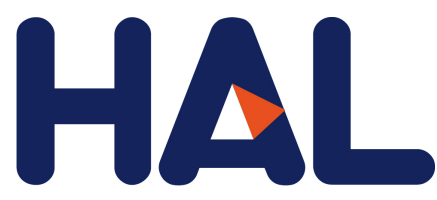

archives-ouvertes

\section{Evidence of the impact of urbanization on the hydrological regime of a medium-sized periurban catchment in France}

I. Braud, P. Breil, F. Thollet, M. Lagouy, F. Branger, C. Jacqueminet, S.

Kermadi, K. Michel

\section{To cite this version:}

I. Braud, P. Breil, F. Thollet, M. Lagouy, F. Branger, et al.. Evidence of the impact of urbanization on the hydrological regime of a medium-sized periurban catchment in France. Journal of Hydrology, Elsevier, 2013, 485, p. 5 - p. 23. <10.1016/j.jhydrol.2012.04.049>. <hal-00859952>

\section{HAL Id: hal-00859952 \\ https://hal.archives-ouvertes.fr/hal-00859952}

Submitted on 9 Sep 2013

HAL is a multi-disciplinary open access archive for the deposit and dissemination of scientific research documents, whether they are published or not. The documents may come from teaching and research institutions in France or abroad, or from public or private research centers.
L'archive ouverte pluridisciplinaire $\mathbf{H A L}$, est destinée au dépôt et à la diffusion de documents scientifiques de niveau recherche, publiés ou non, émanant des établissements d'enseignement et de recherche français ou étrangers, des laboratoires publics ou privés. 


\section{Evidence of the impact of urbanization on the hydrological regime of a medium-sized periurban catchment in France}

3

Braud, I., Breil, P., Thollet, F., Lagouy, M, Branger, F.

5

6 Irstea, UR HHLY, Hydrology- Hydraulics, CP 220, 3bis Quai Chauveau, F-69336 Lyon,

8

9 Jacqueminet, C., Kermadi, S., Michel, K.

10 Université de Lyon, UMR CNRS EVS, 18 Rue Chevreul, 69363 Lyon Cedex 7, France

11

12

13

14

15

16

17

18

19 Published in Journal of Hydrology, 485, 5-23, DOI: 10.1016/j.jhydrol.2012.04.049.

20

21

22Corresponding author: Isabelle BRAUD, Irstea, UR HHLY, CP 220, 3 bis Quai Chauveau, F2369336 Lyon, France. Isabelle.braud@irstea.fr

24

25

26

27

28

29

30Journal of Hydrology, Special issue about the Hydrology of periurban catchments,

31DOI: 10.1016/j.jhydrol.2012.04.049

32 


\section{Abstract}

2In this paper we explore several indicators to evidence the impact of land use change, and 3 particularly of urbanization/artificialization on discharge series of periurban catchments. A 4 first set of indicators is derived from the literature and describes the monthly and annual 5hydrological regime, low flows and high flows, and flow components. Statistical tests are also 6applied to assess the existence of trends/ruptures on the longest time series. In addition, new 7indicators, especially built to show the impact of Sewer Overflow Devices (SODs) and 8infiltration into sewer networks are proposed. The method is applied to the Yzeron $\left(150 \mathrm{~km}^{2}\right)$ 9catchment, located close to Lyon city (France) where various discharge gauges with a variable 10time step are available on sub-catchments ranging from a few to $130 \mathrm{~km}^{2}$ (some of them 11 nested), with a large variety of land uses (forest, agricultural land, artificialized areas). In 12addition, discharge is also measured in a SOD and a combined sewer network so that the 13relevance of the new proposed indicators can be assessed. In the largest sub-catchments, the 14results show a decrease of specific discharge from upstream to downstream corresponding to 15 an increase of artificialized areas, except for high flows. When a SOD is present, the specific 16discharge is increased for frequencies larger than $50 \%$, and the frequency of zero daily 17discharge is decreased. Waste water can be the only source of water in autumn month in a 4.1 $18 \mathrm{~km}^{2}$ sub-catchment. Base flow is also decreased for the most urbanized catchments. Our 19results confirm the impact of SODs on the modification of the flood regime, with an increase 20of frequent floods, but a marginal impact on the largest floods, mainly governed by saturation 21 of the rural parts of the catchments. The decomposition of the sewer discharge shows that, on 22an annual basis, infiltration in the sewer network accounts for $30 \%$ of the total discharge and 23runoff due to rainwater to about $40 \%$ (the remaining being composed of the waste water 24discharge). It can explain the decrease of base flow. Our analysis shows that, for periurban 25 catchments, a long term monitoring of nested sub-catchments and infrastructures (SODs, 26sewer networks) with a small time step, is very valuable and provides data allowing a 27 quantitative assessment of the impact of urbanization on the whole hydrological regime. 28

29Keywords: Suburban/periurban rivers, hydrological regime, high flow, low flow, impact of 30urbanization 


\section{Introduction}

2

3Projections of population growth states that about $60 \%$ of the worldwide population is 4expected to live in towns in 2030 (Paul and Meyer, 2001). Around big cities, periurban areas 5are often the most affected by the corresponding urbanization (e.g. Meija and Moglen., 2010). 6In this paper, the word periurban, used in Europe and Australia, will refer to catchments made 7of a mixture of natural or agricultural lands, and urbanized areas. In the US, the word 8suburban is most often used, but it refers generally to residential areas with houses and 9gardens. Urbanization increases imperviousness of previously natural or agricultural areas. 10Construction of built-up areas is generally associated with the building of artificial structures 11 such as road networks, drinkable, rainwater or sewer networks. These changes have an impact 12 on the water cycle and aquatic ecosystems, due to the increase and acceleration of surface 13runoff, decrease of groundwater recharge and a modification of natural water pathways due to 14the artificial networks (e.g. Bras and Perkins, 1975; Chocat et al., 2001; Booth et al., 2002; 15Randhir, 2003; Matteo et al., 2006; Marsalek et al., 2007). This can lead to flooding, pollution 16and erosion problems within periurban rivers. In some areas, equipped with Combined Sewer 17Systems (CSSs), Sewer Overflow Devices (SODs) are introduced. When the sewer network is 18overflowed, it delivers polluted water to the river. This can lead to incision and erosion 19problems, which perturb the ecological status of the rivers (e.g. Hatt et al., 2004; Walsh et al., 202005; Lafont et al., 2006). In addition, periurban catchments have a complex structure, made 21 of a mixture of natural, agricultural and urbanized areas, and are evolving very quickly (e.g. 22Beighley et al., 2003; Radojevic et al., 2010; Jankowfsky, 2011).

23Studies of land use change impact on the hydrological regime generally analyse long term 24time series or long term simulations, and not only events. The objective is not to reproduce 25 some historical events for sizing hydraulic works, but to get an appraisal of the change of the 26whole river regime. Appropriate criteria and indicators relevant to reveal the impact of land 27use change on this river regime must therefore be defined. In the following, the discussion 28 will be restricted to indicators related to quantitative hydrology. Lots of other indicators have 29 been defined to quantify the ecological status of receiving waters, based on chemistry, 30 biology, etc (e.g. Walsh et al., 2005), in particular in Europe with the Water Framework 31Directive. But they are beyond the scope of this paper. In the remaining of the paper, the word 32 indicator will be used in a broad sense and will include both hydrological variables and 33 quantities derived from discharge data analysis. 
1The literature dealing with the impact of climate change, land use/ land cover change on the 2 water cycle and hydrological model evaluation was reviewed. The objective was to identify 3 the hydrological indicators used by their authors to quantify the impact on discharge data. A 4review of climate change studies is provided by Praskievicz and Chang (2009). Examples of 5land use change studies, mainly related to the impact of deforestation/aforestation on the 6water cycle can be found in Ott and Uhlenbrook (2004), Wang et al. (2007), Archer (2007) 7and Bathurst et al. (2011). These studies are either based on model results or on data analysis 8(Table 1). A large number of the experimental studies are based on paired catchments, where 9natural and preserved catchments are compared to disturbed catchments (Table 1). Vazquez et 10al. (2008) and Willems (2009) introduced several criteria which provide information on the 11performance of a model for several ranges of discharges. These indicators include the 12components of stream flow: base flow, inter flow and quick flow, as well a Peak Over 13Threshold (POT) analysis (Stedinger et al., 1992) both for low flows and high flows. From 14this literature review we have extracted 5 classes of indicators used to examine the impact of 15land use/land cover change on discharge time series. They are summarized in Table 1, which 16also presents the corresponding references.

\section{7}

19The first class of indicators in Table 1 is related to the hydrological regime where the 20indicators are the mean annual runoff, its seasonal components, discharge quantiles and flow 21duration curves.

22The second class of indicators is related to high flows: value and/or date of the annual 23maximum discharge, peak over threshold (POT) analysis which studies peak flow. The QdF 24- Discharge - duration - frequency analysis (Galéa and Prudhomme, 1994, 1997; Javelle et 25al., 1999), an extension of POT analysis to different characteristic durations and not only to 26the instantaneous maximum, is also used to study high flows.

27Low flow indicators form the third class of indicators. They include value and date of 28 minimum annual discharge, frequency of zero discharge, base flow index defined as the ratio 29 between annual base flow and total annual flow, POT analysis for low flow (Willems, 2009). 30The fourth class of indicators is based on hydrograph analysis. It includes the study of event 31 characteristics (runoff coefficient, rising and falling limbs of hydrographs), the quantification 32of flow components based on the separation into base flow, interflow and quick flow (Blume 33et al., 2007; Willems, 2009). Archer (2007) and Archer et al. (2010) introduce more 34 sophisticated indicators based on the analysis of rising and falling limbs of discharge series, 
1or their rate of change. These indicators are the number and duration of exceedance of 2 multiple of the annual discharge. These indicators are relevant to identify quick disturbances 3in hydrographs.

4Finally the fifth class of indicators is based on statistical analyses of discharge time series, 5 mainly relevant when long time series are available. This includes the results of statistical 6tests, comparing if differences between various periods are significant (e.g. Tong, 1990; 7Wang et al.,2007; Radojevic et al., 2010), the results of trend analysis (e.g. Claessens et al., 82006). The results of regression analysis or neural network models, proposed by some authors 9to relate hydrological characteristics to climate or landscape variables such as imperviousness 10(Tetzlaff et al., 2005; Dow, 2007; Wang et al., 2007; Arrigoni et al., 2010) can also be 11 included in this fifth class.

\section{2}

13In urbanized areas, as can be seen from Table 1, the analysis is often restricted to mean annual 14runoff (Beighley et al., 2003; Claessens et al., 2006); high flow with indicators such as annual 15peak discharge (Beighley et al., 2003; Burns et al., 2005), QdF analysis (Radojevic et al., 162010) and/or to the study of selected events (Ott and Uhlenbrook, 2004; Chormanski et al., 172008; Meierdiercks et al., 2010). But this may not be sufficient for all applications, in 18particular when addressing the quality of receiving waters. For ecological problems, the 19whole hydrological regime, and in particular low flows are also important. Walsh et al. (2005) 20suggest that a good target for the rehabilitation of rivers affected by urbanization would be to 21 go back to "near natural" surface flow conditions. This requires the characterization of the 22whole range of discharges. Indicators of Hydrological Alteration (IHA) spanning all the 23 hydrological regime to compare pre and post river flow management with an emphasis to 24stream ecology are proposed by Richter et al. (1996, 1997, 2003). It includes timing of annual 25 extreme water conditions; frequency and duration of high/low pulses; rate/frequency of water 26 condition changes. Jacobson (2011) also provides a review of the impact of imperviousness in 27urban catchments.

28Response times of impervious areas are much shorter than those of natural areas. For small 29 periurban catchments, with response time of less than one day, indicators based on daily 30discharge may not be fully relevant. In addition, given the very short functioning time of 31SODs, specific analyses are required to fully evidence the impact of the urban areas on the 32river flow, especially for small catchments $\left(\mathrm{a}\right.$ few $\left.\mathrm{km}^{2}\right)$. Therefore the analysis of indicators 33based on smaller time steps should be contemplated. Some authors also suggest that 34periurbanization mainly affect frequent floods (e.g. Radojevic et al., 2010) like observed 
1when studying the impact of forest or deforestation on floods (Bathurst et al., 2011). 2Therefore indicators based only on peak discharge or extreme events may not be relevant for 3assessing the impact of urbanization on the water regime, and the whole range of floods must 4be investigated. Another specificity of periurban catchments is the impact of sewer networks, 5 installed to manage both waste water and rainwater. In general those networks are not 6 watertight and infiltration of clear water in the sewer system is very common (e.g. Breil et al, 71993; Berthier et al., 2004; Rodriguez et al., 2008). This may have an impact on the low flow 8within the rivers (e.g. Gufstafsson et al., 1997) and should also be considered.

9In order to characterize the impact of urbanization on periurban rivers discharge, paired 10catchments studies, comparing a natural and an urbanized catchments would be the best way 11 to get the answer. When trying to assess land use change impacts on discharge, it is also 12 sometimes difficult to distinguish between climate variability and land use impact (e.g. 13Ashagrie et al., 2006). Sub-periods comparison for instance may be affected by climate 14variability which can lower the significance of the results. Some authors have proposed 15methods to filter climate variability and highlight the impact of land use by removing climate 16variability using regressions from a reference period, in general considered as undisturbed 17(e.g. Dow, 2007; Wang et al., 2007; Arrigoni et al., 2010). However, those methods may be of 18limited use when recorded data have started as the same time as urbanization (i.e. in the 191970s, as it is the case in France). And it is not obvious to find "natural" catchments other 20things being equal. Therefore, there is a need to develop specific methods which cope with 21existing data series and try to separate the impact of land use change/ urbanization/ 22 management structures from the natural variability of discharge time series. This direction is 23explored in this paper for small to medium-sized periurban catchments, that range from some 24 hectares to some tenth/hundreds of squared kilometres. This analysis is complementary to the 25 set of indicators identified in the previous literature review.

\section{6}

27The objectives of the paper can therefore be stated as follows: are we able to define indicators 28revealing and possibly quantifying the impact of land use change and in particular 29artificialization on the hydrological regime of small to medium size periurban catchments? 30The study is conducted in two steps. First some indicators characterizing the discharge time 31 series, derived from the above cited literature, are assessed. Then, given their identified 32limitations, essentially in taking into account the effect of sewer systems and SODs, specific 33approaches, adapted to periurban catchments are introduced and discussed. The methods are 34applied to the Yzeron catchment, located close to the city of Lyon, France where quite long 
1time series of both rainfall and discharge are available for nested sub-catchments 2 encompassing various ranges of urbanization and sizes. The results are discussed in order to 3 define the advantages/limitations of the retained indicators.

4

\section{Case study}

\subsection{Context of the study and presentation of the catchment}

7The Yzeron catchment $\left(150 \mathrm{~km}^{2}\right)$ is located to the south-west of Lyon city (Figure 1). It forms 8part of the Observatoire de Terrain en Hydrologie Urbaine (OTHU, 2011) long term 9observatory. It is representative of French periurban areas and is characterized by a marked 10topography (Figure 1). The outlet reaches the Rhône river at the elevation of $162 \mathrm{~m}$ and the 11 highest points culminates at $917 \mathrm{~m}$ above see level. The slope map calculated from a $25 \mathrm{~m}$ 12resolution Digital Elevation Model (DEM), derived from IGN BDTopo® shows that more 13than $50 \%$ of the catchment has slopes larger than 10\% (Gnouma, 2006). The geology is 14 contrasted with crystalline formations (granite, gneiss ) in the western part of the catchment 15and more alluvial and glacier formations in the eastern part. This led to a complex soil types 16map with 22 cartographic units identified in the soil map (SIRA, 2011). The land use is 17heterogeneous. The upstream and western part of the basin is limited by a range of hills 18 covered with forests. The intermediate part is mainly covered with grassland and cultivated 19lands, mixed with urban nucleus. Thin green corridors remain along rivers, covered with 20deciduous trees. The downstream part is mainly covered with densely urbanized areas (Figure 212c).

22A fast progression of urbanization is observed since the eighties (Cottet, 2005; Gnouma, 232006, Radojevic et al., 2010). This evolution generally develops in the form of small urban 24 centres that expand from old villages, along road networks, following topographic constraints 25 that are imposed by the river networks. A recent analysis was conducted to quantify the 26increase of urbanization in this catchment (Jacqueminet et al., 2011; Kermadi et al., submitted 27 for publication). A manual digitalization of aerial photographs allowed the identification of 28artificialized surfaces including the urban parcels, parkings, industries and their green fraction 29 (gardens, parks) (Figure 3). The percentage of artificialized surfaces was $22 \%$ of the 30catchment area in 1970, 33\% in 1990 and 36\% in 2008 (Figure 2), showing a slight decrease 31 in the rate of urbanization between 1990 and 2008, as compared to the period 1970-1990. A 32similar analysis based on SPOT images analysis allowed the quantification of impervious 33 areas which were found to cover $15 \%$ of the catchment area in $1990,18 \%$ in 1999 and $23 \%$ in 
12008. The difference between both image treatments can be seen by comparing Figure 1 2which shows the impervious areas and Figure 2c, which shows the artificialized areas for year 32008.

4The area is prone to sharp Mediterranean-type flood events due to its steep topography in the 5upstream part and limited soil water storage capacity overall. The response time of the 6catchment is about 12 hours at $130 \mathrm{~km}^{2}$, causing sometimes flooding in the downstream town 7of Oullins. An increase in the frequency of flooding has been observed in the recent years 8(Radojevic et al., 2010). The water responsible from these flooding mainly comes from the 9rural part of the catchment, but its effect can be enhanced by the fast contribution of urbanized 10zones. The water coming from combined sewer overflow devices is rich of sediments and 11 pollutions, causing quality problems in the rivers, especially during summer storms, where 12 most of the water reaching the river comes from urbanized areas via SODs (Lafont et al., 132006). Increased erosion of the river banks has also been evidenced with impact on the 14ecosystems (Schmitt et al., 2008).

15The Yzeron catchment was recently studied within the framework of the AVuPUR (Assessing 16the Vulnerability of Peri-Urban Rivers) project (Braud et al., 2010). The aim of the project 17 was to increase the knowledge of the functioning and behaviour of periurban catchment 18 hydrology and to propose modelling tools, adapted to those catchments. The study presented 19in this paper is a contribution to this project. The indicators discussed here are also relevant 20 for model evaluation.

21

\subsection{Available data}

23 Rainfall and climate data: A network of rain gauges was set up over the Grand Lyon area in 241985. It includes 28 rain gauges, 4 of which are located within the Yzeron catchment, but 25mainly in the eastern part of the catchment (Figure 1). The rainfall is recorded continuously 26with a 6 minutes time step and all the data set is available until 2010. In order to better 27document the research catchment and the mountainous area, Cemagref has also installed 28complementary rain gauges with a variable time step. The oldest ones were installed in 1997 29(Pollionnay and Grézieu) and the network is continuously upgraded since then. The daily data 30(1921-2009) from the synoptic Bron station, located about $20 \mathrm{~km}$ east of the catchment, were 31 also used.

32The SAFRAN reanalysis data set (Quintana-Segui et al., 2008; Vidal et al., 2010), which 33 provides the climate variables over a $8 \times 8 \mathrm{~km}^{2}$ grid is also available for the grid points 
1 covering the Yzeron catchment over the 1970-2010 period with an hourly time step. This data 2set is the only one available to document the climate (air temperature and humidity, wind 3 speed, long and short wave radiation). The SAFRAN data were used to compute the reference 4evapotranspiration, PET, following the FAO (1998) method.

5

6 Stream flow data: Two gauges from the national HYDRO data base, maintained by DREAL 7Rhône-Alpes are available on the catchment: the Craponne station $\left(48 \mathrm{~km}^{2}\right)$ since 1969, and 8the Taffignon station $\left(130 \mathrm{~km}^{2}\right)$ since 1988 (Figure 1). These two stations are nested. The data 9are available with a variable time step. Three other stations from Cemagref are also available. 10They sample the Mercier $\left(7 \mathrm{~km}^{2}\right)$, Chaudanne upstream a sewer overflow device 11(Upstream_SOD1) $\left(2.19 \mathrm{~km}^{2}\right)$, Chaudanne at La Léchère $\left(2.9-4.1 \mathrm{~km}^{2}\right)$ experimental sub12 catchments (Figure 1). The last two stations are nested. The data are registered with a variable 13time step. In addition, in the Chaudanne catchment, data are collected at the outlet of the 14sewer overflow device (SOD1) since 2001. Discharge is also measured since 2001 in the 15 combined sewer system (CSS) which is directed to the WWTP but sometimes overflows in 16the SOD1 (Figure 3). The main characteristics of the gauging stations are summarized in 17Table 2 and Figure 4 provides the land use encountered within the sub-catchments, using 18three main classes: wooded areas, agricultural land and artificialized areas. We must also 19mention the existence of additional SODs just upstream the gauging stations of La Léchère 20(SOD2) (Figure 3) and Craponne. The methodology presented in section 3.2 will be used to 21assess the impact of these SODs on the discharge measured at the downstream gauging 22 stations.

23The discharge gauging stations network is quite original due to the range of scales and variety 24of land uses which are sampled (Table 2 and Figure 4). The length of the series is also very 25 valuable to evidence the impact of land use change on river discharge.

\section{6}

\subsection{Summary of previous researches}

28The Yzeron catchment is studied for about 20 years. In the following, we only summarize the 29studies directly related with hydrology and water fluxes. Radojevic (2002) and Radojevich et 30al. (2010) analysed the rainfall and stream flow data (Craponne and Taffignon stations) over 31the 1969-1978 and 1988-1997 decades. The rainfall series showed significant differences 32between both decades, with an increase of maximum daily rainfall in the 1988-1997 period. 33This analysis was updated using the climatic data presented above (Bron rainfall daily time 
1series and SAFRAN daily climatic data) in order to detect possible changes in the 2climate/rainfall forcing (Kermadi et al., 2011; Braud, 2011). On the rainfall data, a significant 3increase (Mann Kendall test (Mann and Whitney, 1947) at the 5\% level) of the annual 4 maximum of 5, 10, 15-day cumulative rainfall was found for the Bron station in the 192052010 period, with a rupture detected in 1974 by the Pettitt test (1976). No significant 6 trends/ruptures were found when the period was restricted to the 1970-2009 period. The 7analysis of the daily SAFRAN data on the 1970-2009 period showed a significant increase (at 8the $1 \%$ level) of the annual mean temperature of $0.52{ }^{\circ} \mathrm{C}$ every 10 years. But no significant 9trend in annual PET was found. On the other hand, the Pettitt test show a significant (at the $105 \%$ level) rupture of the annual PET in 2002, which will have to be confirmed in the future. 11 From all the results obtained on the daily rainfall, temperature and PET data, we concluded 12that it was unlikely that change in the rainfall and climate could have affected the 13hydrological regime on the 1970-2010 study period. However, in the context of urban 14 catchments with short response times, such an analysis should also be conducted with shorter 15time steps. It will be done when longer short time step rainfall series will be available (they 16are presently only 25 years long).

17In the study by Radojevic et al. (2010), the stream flow series showed an increase of frequent 18 floods, whereas large floods were not so affected. The change in frequent floods was 19attributed to the impact of urbanization. Radojevic et al. (2010) also used a modelling 20approach to asses the possible impact of urbanization on the hydrological regime, through the 21 impact on the discharge - duration - frequency (QdF) curves. But their analysis is restricted 22to two short periods of about 10 years, and more than 10 years additional data are now 23available. Gnouma (2006) analysed the data from the Craponne, Mercier and Chaudanne sub24 catchments, and tried to propose monthly water balance. The analysis was restricted to the 251997-2004 period.

26In the present study, the discharge data analysis will be extended to include the whole 27available period (until 2010) and all stream flow gauges will be considered. The aim is the 28assessment of indicators, relevant to evidence the impact of land use change on the discharge 29time series. These indicators include annual and monthly discharge, base flow index, peak 30over threshold (POT), QdF analysis and flow components deduced from hydrographs 31 decomposition. The analysis provides elements for a better understanding of the catchment 32 behaviour, both for its rural and urban components. The derived data and synthesis are also 33useful for the evaluation/validation of the models developed within the AVuPUR project. 


\section{Methodology}

3In section 3.1, we first assess indicators taken from the five classes that were identified in the 4literature review, as our objective was to qualify the impact of land use change and 5urbanization on the whole hydrological regime: flow duration curves, low flows, high flows. 6The flow components derived from the hydrograph decomposition were also considered as 7 urbanization is suspected to increase quick flow and decrease base flow. Finally, as one of the 8discharge series was long enough, statistical tests (trends/ruptures) were also applied to this 9time series.

10In section 3.2, we present methods specifically developed to evidence the impact of sewer 11 systems and sewer overflow devices (SODs) on the river discharge time series. 12

\subsection{Indicators derived from the literature}

14The objective of this analysis is to describe and characterize the discharges time series at a 15 given location. Whenever possible the indicators will be adapted/normalized so that 16comparison between different catchments of various sizes and/or various land use become 17possible.

\section{Hydrological regime:}

19For the characterization of the hydrological regime (annual, monthly and daily time step), the 20variable time step stream flow data were first interpolated to a 30 (respectively 60) minutes 21time step for the Pollionnay, Upstream_SOD1, La Léchère stations (respectively Craponne 22and Taffignon stations) and then aggregated to daily, monthly and annual time step from 23 which the hydrological regime was calculated (Sauquet et al., 2000, 2008). Missing daily 24values were replaced by the interannual monthly average corresponding to the month of the 25 missing data.

26From the daily discharges we also derived the flow duration curves (FDCs). They are 27obtained by ordering all the daily discharge values in decreasing order. Each ordered 28discharge value $Q_{f}$ is associated with an empirical frequency which is the probability of 29finding a value $Y$, larger or equal to $Q_{f}$.

$$
\operatorname{Pr} o b\left(Y \geq Q_{f}\right)=\frac{r}{N}
$$

31 where $N$ is the total number of observations and $r$ is the rank of observation $Q_{f}$. 
1In order to compare data from catchments of different sizes and identify the possible impact 2of land use on the discharge, it is convenient to normalize the discharge data before 3 calculating the flow duration curves. The most obvious choice is to compute specific 4discharges by dividing all the data by the catchment area. The advantage is that this method 5 provides water heights comparable to rainfall heights, which can be directly used to compute 6the water balance or runoff coefficients. However, in periurban catchments, especially 7equipped with combined sewer systems, this is not so obvious (Jankowfsky, 2011). 8Jankowfsky (2011) shows that, in such catchments, the boundary is not only dependent on 9topography, but is influenced by the sewer systems. The areas connected to the river via sewer 10overflow devices are only contributing to the streamflow when the sewer systems overflows. 11 In addition, only part of this runoff drains into the river, because part of it continues to reach 12the Waste Water Treatement Plant (WWTP). For the Chaudanne at La Léchère catchment, 13Jankowfsky (2011) shows that under dry conditions, the area of the catchment is $2.9 \mathrm{~km}^{2}$, 14 whereas it reaches $4.1 \mathrm{~km}^{2}$ when all the SODs are activated. This result shows that using the 15 specific discharge in periurban watersheds may lead to some problems and that this quantity, 16as well as runoff height and runoff coefficients must be used with caution.

17The second option is to normalize discharge data with the average annual discharge (e.g. 18Sauquet et al., 2008). This indicator is independent of the catchment area estimation. 19However, if the mean annual discharge changes with time due to land use modifications, this 20may bias the results. Comparison between catchments is therefore more difficult and only 21 normalisation based on specific discharges will be discussed in the remaining of the paper.

\section{Low flows:}

23The base flow was estimated using the Tallaksen and Van Lanen (2004) algorithm on the 24daily data. The base flow was estimated by linear interpolation between $n$ points 25 corresponding to the local minima of $n$ periods of 5-days duration without intersection. The 26BFI (Base Flow Index), which is defined as the average of the base flow divided by the mean 27interannual discharge of the time series, was selected in this study. It is a non-dimensional 28index which allows comparison between catchments. Low flow were also characterized with 29the frequency of zero daily discharge (Richter et al., 1996).

\section{High flows:}

31 Variable time step discharge time series were used for the discharge- duration- frequency 32analysis $(\mathrm{QdF})$. The method provides a theoretical description of floods for several durations. 33The studied variable was the maximum discharge continuously exceeded during the duration $34 d, Q C X_{d}$ (Figure 5a) The analysis was performed in several steps. 
1 - A characteristic flood duration was estimated for each gauge. The analysis was performed

2 using data from which the base flow (calculated as described above) had been removed. As

3 the base flow data were available at the daily time step, an interpolation of base flow at the

4 variable time step was performed before removing it from the variable time step time

5 series. An automatic program has been developed which selects the hydrographs around

6 major floods. A discharge threshold, determined from the POT analysis (see below) is

7 prescribed for the events selection and all the floods higher than this threshold are retained.

8 Each hydrograph is scaled by its maximum peak discharge $Q_{\max }$. Therefore all the

9 hydrographs have a maximum value of 1 (and can be compared amongst catchments). From

10 all the hydrographs, we compute the median hydrograph. The characteristic flood duration

$11 \theta$ is then calculated as the duration where $Q / Q_{\max }=0.5$ in this median hydrograph (Figure

$125 b)$. An iteration with the next step may be required to properly fix the discharge threshold.

13 - The next step is the extraction of independent values of floods for various durations $d$. One

14 value per year (annual maximum) can be extracted, but in order to increase the sample size,

15 the Peak Over Threshold approach was used. We tested extractions with an average of 2

16 and 4 floods per year in the analysis. As we are interested not only in extreme floods but

17 also in frequent floods and given the shortness of some of the time series, the extraction

18 with 4 floods per year was finally used and will be presented below. The corresponding

19 threshold was automatically determined so that the target average flood number per year

20 was obtained (Lang et al., 1999). The procedure also ensures independence of the selected

21 events. The analysis was performed on the hydrological years (from September 1 to August

$2231)$ for the instantaneous flood peak $(d=0)$ and for $d / 8, d / 4, d / 2 ., d, 3 d$. For the various

23 gauges, the duration $d$ was chosen close to the characteristic flood duration $\theta$ determined in

24 the previous step. Next, the empirical probability of non-exceedance of the value $x$

$$
\operatorname{Pr} o b\left(Q C X_{d} \leq x\right)=F(x)
$$

26 was calculated on the sampled variable $Q C X_{d}$. From this relation, it is possible to calculate

27 the quantile $x(T)$ of return period $T$, associated with the $F$ law.

\section{Hydrograph separation:}

29In this study, we used the WETSPRO tool proposed by Willems (2009) to compute base flow, 30inter flow (sub-surface flow) and quick flow. This method is an extension of the recursive 31 digital filter of Chapman (1991). It assumes that the recession curve can be adjusted with an 32exponential model. The recession constant, $k$, of the exponential model corresponds to the 33 time in which the flow is reduced by a factor $\exp (-1)=0.37$ during dry weather periods. The 
1method of Willems (2009) includes a second parameter $w$, which corresponds to the average 2 fraction of the sum of the quick and inter flow volume over the total flow volume. The 3filtering procedure is first applied to extract the base flow. It is then repeated to extract the 4interflow on the (total - base flow) time series. The values of the $k$ and $w$ parameters were 5 determined manually by trials and errors so that the base flow fraction was close to the BFI 6determined previously. The analysis was performed for the Craponne and Taffignon data 7using daily data, and the Pollionnay, Upstream_SOD1 and La Léchère gauges, using two8hours time step data in order to capture the inter flow.

\section{9 $\underline{\text { Statistical tests: }}$}

10The Craponne gauging station was the only station with a long enough (40 years) time series 11 to perform trend/rupture statistical tests. The Mann Kendall (Mann and Whitney, 1947) and 12Pettitt (1979) tests were used for trend and rupture analyses respectively. The analysed 13 variables were the mean annual discharge, BFI, components of the flow as derived from the 14hydrograph separation, the POT values (using an extraction of two and four floods per year 15on variable time step time series), following the methodology proposed by Renard et al. 16(2006) and Lang et al. (2006).

17

183.2. Methods specific to the existence of sewer overflow devices and sewer 19 networks

20As said before, given the quick response time of the urban parts and the very short 21 functioning time of SODs, the indicators proposed in the previous section are not sufficient to 22fully evidence the impact of the urban areas on the river flow, especially for small catchments 23(a few $\mathrm{km}^{2}$ ). Therefore, we propose specific methods, particularly adapted to these conditions. 24These methods rely on filtering techniques of the discharge time series. Two types of 25applications were developed (Table 3):

26Filtering of SODs discharge to derive "pseudo-natural" discharge series. In order to get a 27clear signature of the SOD on the river discharge time series, the SOD must be located 28upstream and close to the discharge gauging station $(10$ to $100 \mathrm{~m})$. The filtering method is 29applicable to variable time steps time series as it takes benefit of the fact that, in case of SOD 30overflows, the discharge will increase rapidly and the measurement points will be more 31 frequent. The filtering is based on a moving average with a constant number of points. 32 Therefore the time step of the filtering will be much shorter when the response is quicker 33(activation of the SOD) than when the response is slower. The method was applied to the La 
1Lèchere and Craponne stations where a SOD is present less than $100 \mathrm{~m}$ upstream, with a 4 2 points moving average. This leads to two additional time series corresponding to the SOD 3discharge (indexed SOD in Table 3) and the river discharge if the SOD was absent (indexed 4Rural in Table 3).

5Filtering of the combined sewer systems discharge (CSS) series. In this case, the method 6allows the separation of the measured discharge between waste water (WW), parasite clear 7 groundwater infiltration in the sewer network $(\mathrm{GW})$ and the runoff component $(\mathrm{RW})$. Its 8application combines times series of Combined Sewer System (CSS) discharge, rainfall data, 9SOD discharge (when a SOD is present). Contrarily to the previous case, the filtering method 10is applied to fixed time step time series (in our case 6 min time step given the size of the 11 catchment and the response time) in order to process simultaneously the various time series. 12The fixed time step time series are obtained from linear interpolation of the variable time step 13times series.

14The principles underlying the method are summarized in Figure 6 and detailed below.

15 - Step 1: determination of the WW fraction. This step is conducted in two phases. Step1a:

16 During the night, as the catchment is quite small, it is assumed that the waster water (WW)

17 is zero. In dry period conditions, the discharge measured in the sewer system during the

18 night can therefore be assumed to be clear parasite groundwater infiltration (GW). This GW

19 water is obtained by using a moving average tracking the daily minimum discharge (in our

20 case a moving average calculated using 240 points, corresponding to $24 \mathrm{~h}$ of 6 min time step

21 data). Step 1b: This clear parasite water infiltration is subtracted from the CSS discharge,

22 leading to a residual time series (CSS - GW). To estimate the waste water discharge, it is

23 assumed that, during dry weather periods, the CSS-GW discharge is equal to the waste

24 discharge (WW). A weekly averaged cycle is calculated from the 6 min time step data

25 during dry weather. This weekly cycle takes into account week and week-end days that

26 have specific patterns.

27 - Step 2: The WW series is substracted from the CSS data. This leads to a time series of 28 runoff + infiltrated groundwater data $(\mathrm{RW}+\mathrm{GW})$. The same moving average tracking the

29 daily minimum discharge is applied once again to separate the RW and GW discharges.

30 - Step 3: If a SOD exists, its contribution is added to the runoff because the water which

31 overflows the SOD is also generated by runoff. This leads to the final value of the runoff

32 series (RW + SOD). 
1Table 3 presents a synthesis of the various time series, derived using the two filtering methods 2and the name they will be referred to in the paper. The same indicators as those presented in 3section 3.1 were applied to the filtered time series, when relevant.

4

\section{Results}

6The results section contains two sub-sections. First we present the results of the observed data 7analysis, based on the methods described in section 3.1. Second we present the result of the 8filtering methods presented in section 3.2

9

\subsection{Analysis of observed discharge time series}

\subsubsection{Hydrological regime}

14Table 4 provides the values of the mean annual discharge (and specific discharge when 15relevant) and 50\% quantile of the FDC. Figure 7 shows the average monthly specific 16discharge for the 5 gauged stations for the 2005-2010 common measurement period. Table 4 17and Figure 7 show that the "rural" catchments have an average annual specific discharge 18ranging between 5.5 and $6.91 \mathrm{~s} \mathrm{~s}^{-1} \mathrm{~km}^{2}$. They also exhibit similar monthly patterns with higher 19values in spring and winter and low discharge in summer and autumn (Craponne, Pollionnay, 20Upstream_SOD1). On the other hand, the Taffignon station exhibits systematically lower 21 monthly specific discharge than its upstream gauging station Craponne. This is also reflected 22in the average annual specific discharge which is only $5.11 \mathrm{~s}^{-1} \mathrm{~km}^{2}$ as compared to $6.91 \mathrm{~s}^{-1}$ $23 \mathrm{~km}^{2}$ for Craponne. An analysis of the annual runoff coefficient (not shown) confirms that the 24Taffignon values are systematically lower than those of Craponne and the difference in mean 25(0.26 for Craponne and 0.21 for Taffignon) is significant at the $5 \%$ level $(p=0.02$ for the $\mathrm{t}$ 26test). Figure 7 shows that the La Léchère station (when considering the most favourable case 27 with a $2.9 \mathrm{~km}^{2}$ catchment area) has larger values of average monthly discharge than its 28upstream station (Upstream_SOD1) in summer and autumn (May to October ). It can be 29explained by a larger contribution of artificialized areas in summer (see section 4.2.3).

30Figure 8a shows the flow duration curve of the daily specific discharge for the gauged 31catchments: Taffignon, Craponne, Pollionnay, Upstream_SOD1, La_Léchère. It shows that 32the Craponne station has larger specific discharge than the downstream Taffignon station for 33almost all the range of frequencies. The lowest runoff production is therefore generalised for 
1the whole range of discharges (except high flows - see section 4.1.3). The downstream 2La_Léchère station has significantly higher values than the Upstream_SOD1, which is much 3less urbanized than the La_Léchère station (Figure 4), for the frequencies larger than $40 \%$. 4

\subsubsection{Low flows and hydrograph separation}

6Low flows are characterized using the $\%$ of zero daily discharge and the BFI (Table 4). For 7 the gauged catchments, the \% of zero daily discharge ranges between $0.25 \%$ (Craponne) to 831\% (Upstream_SOD1). Note that the Taffignon gauge has a larger frequency of zero 9discharge (5.4\%) than the upstream gauging station Craponne. This confirms the decrease in 10runoff production, already observed on the annual specific discharge and the FDC, from 11 upstream to downstream. On the other hand, the \% of zero daily discharge decrease from $1231.2 \%$ Upstream_SOD1 to $11.1 \%$ at the downstream La Lèchère station (see also Figure $8 \mathrm{a}$ ). 13This increase can be attributed to the impact of urbanization as the additional area is mainly 14composed of artificialized areas (Table 4).

\section{5}

16The BFI values of the observed time series range between 0.26 and 0.54 . Those values are 17 quite low and are characteristic of catchments with a low storage capacity. For the catchments 18 with the lowest \% of artificialized areas (Upstream_SOD1 (24\%), Pollionnay (11\%), 19Craponne (18\%)), the BFI increase with the catchment area, consistently with a decrease of 20 the $\%$ of days with zero discharge (Table 4). The behaviour of the Taffignon station is, once 21again, inverse to what is expected: the BFI decreases between the upstream Craponne and 22downstream Taffignon stations. The lowest specific annual discharge could therefore be 23 explained by a lower base flow.

25Table 5 shows the results of the discharge decomposition into base flow, inter flow, quick 26flow using the WETSPRO tool. The two small rural catchments (Pollionnay and 27Upstream_SOD1) have similar values of the $k$ recession constant (5 days). The quick flow 28represents $43.5 \%$ of the total flow for the Pollionnay station and $49 \%$ for the Upstream_SOD1 29catchment. This can be explained by the difference in land use (mainly forest and crops for 30Pollionnay and crops for Upstream_SOD1), and because crop land has been shown to have a 31 lower infiltration capacity than forest (Gonzalez-Sosa et al., 2010). The recession constant of 32the La_Léchère station is smaller than that of the upstream station Upstream_SOD1, and the $33 \%$ of quick flow is higher (54.4\% against $49 \%$ ), with a lower base flow. This shows the 34impact of the SODs and the urbanized areas which is the dominant land use in the additional 
1area between the two gauges. When comparing the Craponne and Taffignon stations, we can 2 see that the $k$ recession constant increase between the upstream and downstream gauge (28 3 and 35 days respectively). However, the downstream Taffignon gauge has a smaller base flow $4(39.3 \%$ against $49.8 \%)$, as said before, and a higher portion of quick flow (37.6\% against $525.6 \%$ ). This corresponds to an increase of the artificialized surfaces (from $18 \%$ of the total 6 catchment area at Craponne to $31 \%$ of the total catchment area at Taffignon - see Figure 4). 7This analysis confirms the expected impact of urbanization: an increase of quick flow at the 8expense of base flow, but this effect has been quantified here.

\subsubsection{High flows}

11The characteristic flood durations appear in Table 4. Figure 9a shows the normalised median 12 hydrographs for the various observed time series. We remind that the base flow has been 13removed before performing the extraction. For all the catchments, Figure 9a shows that the 14rising limb of the characteristic hydrographs is very sharp (a few hours). On the other hand, 15the catchments with the lowest artificialized area (Craponne, Pollionnay, Upstream_SOD1) 16have a quite heavy and long recession, although the characteristic duration, corresponding to $17 Q / Q_{\max }=0.5$ is short (between 3 and 7 hours, Table 4), except for Upstream_SOD1 where it 18reaches 10 hours. The most artificialized catchments (La Léchère and to a lesser extend 19Taffignon) present characteristic hydrographs with the sharpest rising limbs (less than 5 20hours) and a very quick recession (about 5 hours). Urbanization has therefore a significant 21 impact on the hydrograph shape.

22The maximum daily discharge and their corresponding specific values are provided in Table 234. Figure 10 shows the result of the QdF analysis in terms of specific discharge, for durations $24 d=0$ (maximum instantaneous peak discharge) and $12 \mathrm{~h}$ for the 5 gauged stations. For all the 25 stations, the flood discharge decreases sharply between the two durations, which is consistent 26with the peaky shape of the characteristic flood hydrographs (Figure 9a). For the duration $d=0$ 27 and for a return period of less than ten years, the highest floods are encountered for the 28Pollionnay, Upstream_SOD, Taffignon and Craponne stations, in decreasing order. The most 29rural and natural catchment (Pollionnay) appears the most productive in terms of high floods. 30Contrarily to what is observed for the monthly regime and the low flow, the downstream 31Taffignon station is most productive than the upstream Craponne one for high flows. 32Urbanization may be responsible for this larger runoff for the highest floods. These features 33also hold for the $d=12 \mathrm{~h}$ duration. The results for the La Léchère station are shown using the 34two extreme catchments areas. For the most frequent floods, the specific discharge for $d=0$, is 
1significantly larger than that of the Upstream_SOD1 station, whatever the choice of the 2 catchment area. We can deduce that the urbanization of the downstream part of the catchment 3increase the magnitude of the most frequent floods.

\subsubsection{Statistical tests for the Craponne gauging station}

5The results of the trend and rupture statistical tests performed on the Craponne time series 6(1970-2010) are summarized in Table 6. They show a significant decrease of the \% of base 7 flow and inter flow at the 5\% and 1\% level respectively, whereas the quick flow increase 8 significantly at the $1 \%$ level. The increase in maximum annual discharge is not significant, 9nor the increase in maximum peak discharge. On the other hand, the POT analysis reveals a 10significant increase (at the 5 or 10\% level) of the magnitude of floods for all the durations 11 except $d=0$, when sampling the floods with two floods per year. If the sampling is performed 12 to retain four floods per year, i.e to include less intense floods, none of the trend/rupture 13remains significant (not shown). These results show that a trend is only evidenced for the 14largest floods.

15

\subsection{Application of the filtering methods}

\subsubsection{Evaluation of the SOD discharge filtering method}

18The result of the filtering of SOD discharge is illustrated in Figure 11 for the La Lèchere 19station. This figure shows the initial time series, the calculated La_Léchère_SOD2 and 20La_Léchere_Rural time series. We have also added the SOD1 time series on the graph, in 21 order to assess the relevance of the method. Although the La_Léchère_SOD2 seems to react 22 much more frequently than the SOD1 (the frequency of zero daily discharge are 22.9 and $87 \%$ 23respectively, see Table 4), we can assume that when SOD1 is active, SOD2 should also be 24active. This can allow the validation of the timing of the filtering method. Figure 11 shows 25 that the agreement is reasonable and similar results were obtained on the whole period. The 26total volume discharged by SOD2 represents 5.3\% of the total discharge at La Lèchère 27 gauging station.

28For the Craponne_SOD time series, no data were available for validation. The area drained by 29the SOD is estimated to be about $10 \%$ of the total catchment surface (Table 3 ). The total 30 volume of the SOD discharge represents $7 \%$ of the total Craponne discharge. This figure is 31 reasonable and comparable to that of the La Léchère catchment. In the near future, it will be 32possible to fully validate them, as the La Léchère and Craponne SODs are gauged since 2010. 
1In the remaining of the paper, we will assume that the filtering method is accurate enough so 2that the corresponding data series can be analysed similarly to the truly gauged time series.

\subsubsection{Hydrological regime}

4When considering the reconstructed "rural" time series for the Craponne and La Léchère time 5 series, the average annual specific discharge of the rural time series is $13 \%$ lower for the 6Craponne station and 5\% for the La Léchère station (Table 4).

7This is confirmed (both for the Craponne and La Léchère station) by Figure 12 (top), which 8shows the fraction of the total average monthly discharge coming from the SODs. This 9 contribution of the SODs to the monthly regime ranges from $2-3$ to about $15 \%$ with a clear 10 annual cycle. The highest values occur in summer and autumn, when the natural discharge is 11 the smaller. In this period, the contribution of SODs to the discharge is therefore important in 12a period where the river can be dry (see next section). This can increase pollution problems, 13all the more than discharge is low and dilution effects cannot occur.

\subsubsection{Low flows and high flows}

15The frequency of zero daily discharge for the total, rural and SOD components of the 16Craponne and La Léchère stations (Figure 12, bottom), show very different behaviours 17between the two gauges. Whereas the frequency of zero discharge in the Craponne_SOD is 18quite constant throughout the year, it presents a clear annual cycle at La_Lèchère_SOD2. 19 Values are higher in summer than in winter, which shows that the SOD2 is more frequently 20activated in winter, when the soil conditions are humid, than in summer when they are drier. 21 For the two gauges, the \% of zero daily discharge of the "rural" time series is systematically 22lower than that of the total discharge. For the La Léchère station, the difference can reach $2320 \%$ in September and October. It means that the discharge in the river only comes from the 24SOD2 during this period.

$25 \mathrm{We}$ also see that, when the SODs contribution are filtered, the BFI values are larger than for 26the total discharge (Table 4), showing, as expected that SODs mainly contribute to quick 27 flow.

\subsubsection{Low flows and high flows}

29Figure $9 \mathrm{~b}$ and $9 \mathrm{c}$ show the normalized hydrographs for the total, rural and SOD components 30of the Craponne and La Léchère stations respectively. As expected the SOD hydrographs are 31 very peaky with characteristics flood durations of about $1 \mathrm{~h}$. Although the total and rural 32hydrographs are very close for the La Léchère station, the rural Craponne series shows a 
1much slower recession than the total curve with a doubling of the characteristic flood duration 2 for the rural component. On this gauge, the impact of the SOD seems to be much influential 3on the hydrographs shapes than for the La Léchère catchment.

4Figure 13 shows the QdF analysis for the total, rural and SOD components of both the 5Craponne and La Léchère stations. This figure shows that, for the largest floods, the rural and 6total curves are very close. It suggests that the largest floods are mainly associated with a 7large contribution of the rural area. On the other hand, the impact of SODs is significant for 8 frequent floods, with return period of less than 2 years.

\subsubsection{Analysis of the sewer system components}

10The mean annual values of the sewer discharge components are provided in Table 4. The 11 waste water accounts for $33 \%$ of the total discharge, the rainwater runoff for $38 \%$ and the 12 infiltration of groundwater into the sewer for $30 \%$. The results of the filtering of the sewer 13discharge time series is illustrated in Figure 14 at the monthly time scale for the whole 14measurement period (2001-2010). It shows that the groundwater infiltration exhibits a clear 15annual cycle. It is almost zero in summer when the soil is dry and increases in winter and 16 spring when the soil moisture is higher. The monthly pattern of rainwater runoff follows that 17 of the monthly rainfall. Figure $8 \mathrm{~b}$ shows the FDC of the CSS discharge and its various 18 components. The FDC of the waster water (WW) is very flat as expected from its building. 19Values of CSS_RW+SOD1 below $0.001 \mathrm{~m}^{3} \mathrm{~s}^{-1}$ can be considered as noise, which explain the 20low value of zero daily discharge (about $10 \%$ in Table 4). The average fraction of rainy days 21 is about $50 \%$ and the CSS_RW+SOD component of the CSS discharge is only not null when 22 it rains. For the values larger than $0.001 \mathrm{~m}^{3} \mathrm{~s}^{-1}$, Figure $8 \mathrm{~b}$ shows that the ranges of infiltrated 23 groundwater and runoff discharges are very similar. Groundwater infiltration into the network 24is therefore a major problem for the efficiency of the sewer network. It may explain the larger 25activation of SOD2 in winter when the groundwater table is high (see Figure 12, bottom).

\section{6}

\section{Discussion}

28The importance of data collection. The analysis presented in this paper relies on a nested and 29 complete network of gauging stations, monitoring discharges in sub-catchments with various 30land uses but also on some infrastructures such as SODs and sewer networks. The set up in 31 the Chaudanne sub-catchment is very valuable, as it allows the quantification of the impact of 32SODs and infiltration into the sewer network. However, although lots of efforts were 33dedicated to monitor the various branches, it is still impossible to close the water balance of 
1the catchment (uncertainty of the partition of water between SODs and the Waste Water 2Treatment Plant, partial measurements of the SODs).

3For the type of analysis presented in the paper, the data quality and length of the series is of 4prime importance. The data availability period is very variable (between 5 and 40 years). 5Except Figure 7, all the indicators are calculated using the largest available time series. Due to 6internanual climate variability, which is large in this catchment (the $\mathrm{CV}$ of average annual 7rainfall is $241 \mathrm{~mm}$ at Pollionnay for an average of $746 \mathrm{~mm}$ on the 1997-2009 period), this 8 may induce sampling fluctuations of the indicators. We verified that the conclusions were 9similar when the indicators were calculated on the same period (2005-2010). Another $10 \mathrm{important}$ point is the accuracy of the discharge data. A diagnostic of the gauging stations 11 showed that low flows are generally quite uncertain due to very large sections and a small 12 water height (Pollionnay, Upstream_SOD). This problem is being solved by adding a 13triangular device to get a higher accuracy for small discharges. The Craponne and Taffignon 14stations are considered reliable by their manager (DREAL) and therefore the decrease of 15runoff from upstream to downstream cannot be attributed to measurement problems. The La 16Lèchère station is the most accurate as it is equipped with a calibrated canal, but it may be 17 overflooded for the largest discharges. This can explain the decrease in specific discharge for 18high flows (Figure 10). Branger et al. (2011) proposed a method to assess the accuracy of 19stage-discharge relationship and provide an error bound for each discharge measurement. The 20use of this information was beyond the scope of this paper, but will be useful to better assess 21 the significant changes/trends. In terms of monitoring, progress is under way as new SODs 22are now monitored in the context of the quantification of rejected water in the receiving rivers 23(Water Framework Directive). These new data offer an opportunity to better understand the 24response of urbanized areas in periurban catchments and further validate the filtering method 25leading to the decomposition of total discharge into rural and SOD components. The 26Craponne subcatchment has a quite large area and it may be difficult to discriminate between 27 the influence of the various infrastructures impacting the flow. The new discharges 28 measurements in the SOD will be very valuable as they will allow a better assessment of the 29limits of applicability of the SOD filtering method.

31 Impact of artificialization on the regime and the flow components. Impact on low flows and 32the importance of the sewer network. Two results of this study are particularly striking: the 33decrease of specific discharge from upstream to downstream between the Craponne and 34Taffignon gauges, and the large fraction (30\% of the total discharge) of infiltration into the 
1sewer system calculated for the Chaudanne subcatchment. This figure is high but consistent 2 with independent estimation conducted using punctual measurements during the night by the 3services in charge of the network management. Recently Prigiobbe and Guilianelli (2009) 4reported an infiltration of about $50 \%$ in the old Rome sewer network and $14 \%$ in a recently 5 constructed area. Berthier et al. (2004) found that the contribution of soil water infiltration to 6runoff in sewer pipes was about $15 \%$ in a small residential periurban catchment. On the same 7 catchment, Rodriguez et al. (2008) simulate $11 \%$ of infiltration into the rainwater sewer 8 system and $18 \%$ in the wastewater sewer system. In the Yzeron catchment, the main pipes 9network was built along the valley bottom in the seventies to collect waters from the 10surroundings. Breil et al. (2010) analysed one year of discharge monitoring in the main sewer 11 collector close to the Taffignon station. They estimated the infiltration into the network to be $1227 \%$ of the annual discharge. There is therefore a consistency in the results and infiltration 13into the sewer network can be considered as responsible for the decrease of base flow and 14average monthly discharge between Craponne and Taffignon. The impact of the SODs is also 15 significant on low flows. They significantly impact the frequency of zero discharge and, for 16the smallest sub-catchments where the natural river regime is seasonal, water coming from the 17SODs is the only source of water during a significant part of the year. The impact in terms of 18 water quality is of course important (Lafont et al., 2006). However, in order to conform to the 19water framework directive, the management of rainwater is being reconsidered: where 20possible rain waters are diverted to new separate sewers flowing to retention/detention basins. 21This process is under way in the Chaudanne catchment and should be monitored to quantify 22 its future impact on the river discharge. Another lesson of this study is the importance of $23 \mathrm{knowing}$ precisely the catchments areas. This task is quite simple for natural catchments but is 24much more complicated for periurban catchments (Jankowfsky, 2011). However, such 25 determination is essential to compare various catchments based on specific discharge. A 26normalisation with the mean annual discharge was attempted, but the interpretation of the 27results was not found relevant. This question of catchment area is therefore a major challenge 28 for data interpretation and comparison in periurban catchments.

29Impact on high flows. The results obtained in this paper confirm that for the highest floods, 30the impact of urbanization (via the SODs) is limited. In this case, the rural part of the 31 catchment is the major contributor to floods, which can be explained by saturation of the soil 32 due to long rainfall events. It may be counter-intuitive to see that the most productive 33 catchment for high flows is the less urbanized one (Pollionnay). However, other studies 34(Sarrazin, 2012) have shown that the whole catchment is saturated during the largest floods 
1(corresponding to long lasting events of at least $70-80 \mathrm{~mm}$ ). The whole catchment area is 2therefore contributing to the flow, whereas a part of the rainwater is diverted towards the 3WWTP in the artificialized catchments, even if all the SODs are activated. Our results also 4confirm that SODs mainly impact frequent floods, as already shown by Radojevic et al. 5(2010) using model simulations. Urbanization and catchment artificialization have also an 6impact on the hydrographs dynamics as shown by Figure 9. The most urbanized catchments 7have more peaky flood hydrographs. In order to refine this type of analysis, approaches such 8as those proposed by Archer (2007), Archer et al. (2010) should be investigated in the future, 9as they allow a full exploration of the whole discharge series, by analysing the frequency and 10duration of exceedance of various threshold discharges. In the Yzeron catchment, it has been 11 shown that these variables were very relevant to quantify the impact of SODs on the incision 12and bank erosion risk (Grosprêtre, 2011). In the case of a upstream-downstream gradient of 13urbanization, like in the Yzeron basin, urban generated floods are flowing before the rural 14floods, avoiding peak flood accumulation. The effect of urbanization could be more sensitive 15and may be dramatic if impervious areas extension takes place upstream, increasing the 16probability of concomitancy between urban and rural floods (Ostrowski, 2000; Ostrowki et 17Bras, 2000.). Such an explanation may be invoked to explain the largest specific discharge of 18the downstream Taffingon station, as compared to its upstream Craponne one for high flows. 19Indeed, the Yzeron rivers receives a tributary flowing through a quite densely urbanized area 20before the Taffignon station.

21Statistical tests. Statistical tests were only applied to the longest Craponne time series. They 22highlighted a modification of the components of the flow, with a decrease of base and inter 23flow, and an increase of quick flow. The SODs in this catchment were installed between 1970 24and 1980 and therefore impact most of the available time series (1970-2010). There is also a 25 significant increase of POT discharge (sampling with an average of two floods per year) for 26all the durations, except peak discharge. This can be put in parallel to the increase of 27artificialized surfaces in this catchment between $1970(9 \%)$ and $2008(18 \%)$, all the more than 28no significant change of maximum annual cumulated (1 to 15 days) daily rainfall can be 29 evidenced. For the analysis of floods, an analysis of rainfall with a shorter time step (typically 30hourly) would be necessary but the available time series are too short up to now for such an 31 analysis. In addition, those results on floods must be considered with caution as they are 32 sensitive to the sampling strategy.

33 Towards a perceptual model of the Yzeron catchment behaviour. From the data analysis 34 presented before, we can propose a perceptual model of the Yzeron catchment hydrological 
1 functionning. The rural part of the catchment has a high infiltration capacity (Gonzalez-Sosa 2et al., 2010) but a small storage capacity. Therefore, for the small to medium events, the 3 catchment response is mainly dominated by the quick response of urban areas for the 4 formation of peak discharge and a delayed rural response mainly impacting the recession 5 curve. Frequent floods are increased by the catchment urbanization. For the largest events 6(mainly long duration rainfall events), the catchment response is dominated by the rural 7response due to soil saturation. The river regime is also perturbed by the sewer systems 8through a high rate of infiltration of soil water which is diverted towards the WWTP and 9 contributes to a decrease of base flow in the rivers. On the other hand, SODs have an 10antagonist impact as they provide a significant contribution to the river discharge in summer, 11 especially for small catchments. But their impact is smaller than that of the sewer systems and 12the whole impact is mostly a base flow decrease. However, given the actions planned to 13 improve the quality of the receiving waters (improvement of the tightness of the sewer 14 systems, separation of rainwater and waste water, building of retention basin, etc), the 15discharge monitoring must be continued to see if those actions have a real impact on the 16discharge. The indicators presented in this study can help monitoring the system.

\section{7}

18

\section{Conclusions and perspectives}

20The data analysis presented in this paper provides valuable insight into the periurban Yzeron 21 catchment behaviour. We were able to highlight relevant indicators of the impact of 22urbanization/artificialization on the hydrological regime of periurban rivers. The results were 23obtained thanks to the availability of a long term and rich data set, sampling various aspects 24of the periurban water cycle. These series were relevant for our analysis. However, longer 25 time series and sampling of more infrastructures would be necessary to fully close the water 26balance of such catchments. We have also seen that the determination of the periurban 27 catchment area is also of importance for a correct data analysis. The filtering method 28proposed to decompose the measured discharge into rural and SOD component was found to $29 \mathrm{be}$ efficient in highlighting the major role of SODs on the whole hydrological regime, 30including, mean monthly regime, low flows and high flows. The application of the method 31requires the location of the SOD and gauging station to be very close, and data acquired with 32a variable time step. This findings provide guidelines for the setting of proper monitoring 33networks of those periurban catchments. Finally, the role of water infiltration within the sewer 
1system was highlighted. It was found to account for $30 \%$ of the total combined sewer system 2discharge. There are evidence that this infiltration has an impact on low flow and on a large 3 part of the hydrological regime, by decreasing the water into the stream. This impact is 4important to consider due to its large impact on water quality and on ecosystems.

5The indicators derived in this study are also very useful for the assessment of model results 6set up in the Yzeron catchment both at small scale (Chaudanne and Mercier catchments, 7Jankowfsky et al, 2011) and the Yzeron catchment (Branger et al., 2012).

8Future work would be required to analyse more in depth the events characteristics, such as 9done in Sheeder et al. (2002) or Furusho et al. (2012) and characterize the impact of 10artificialization on the hydrograph shape using for instance methods derived from Archer 11(2007), Archer et al. (2010).

12

\section{Acknowledgements}

14The AVuPUR project was funded by the French National Research Agency (ANR) (contract 15ANR-07-VULN-01). CCVL, IGN, Grand Lyon, Météo-France, Nantes-Métropole, SAGYRC, 16SIAVHY, Sol-Info Rhône-Alpes provided data used in the study. SPOT images were acquired 17thanks to an ISIS contract. Charlotte Michel and Gautier Chapuis helped in processing the 18data. Eric Sauquet and Benjamin Renard provided some of the tools used to process the data. 19Christine Jacqueminet, Saïda Kermadi and Kristell Michel processed the data used to derived 20Figure 2 and 4.

21 


\section{References}

2Archer, D.R., 2007. The use of flow variability analysis to assess the impact of land use

3 change on the paired Plynlimon catchments, mid-Wales. Journal of Hydrology, 347(3-4),

4 487-496.

5Archer, D.R., Climent-Soler, D., Holman, I.P., 2010. Changes in discharge rise and fall rates

6 applied to impact assessment of catchment land use. Hydrology Research, 41(1), 13-26.

7Arrigoni, A.S., Greenwood, M.C., Moore, J.N., 2010. Relative impact of anthropogenic

8 modifications versus climate change on the natural flow regimes of rivers in the Northern

9 Rocky Mountains, United States. Water Resour. Res., 46(12), W12542.

10Ashagrie, A.G., de Laat, P.J.M., de Wit, M.J.M., Tu, M., Uhlenbrook, S., 2006. Detecting the

11 influence of land use changes on discharges and floods in the Meuse River Basin - the

12 predictive power of a ninety-year rainfall-runoff relation? Hydrology and Earth System

13 Sciences, 10(5), 691-701.

14Bathurst, J.C., Iroume, A., Cisneros, F., Fallas, J., Iturraspe, R., Novillo, M.G., Urciuolo, A.,

15 de Bievre, B., Borges, V.G., Coello, C. et al., 2011. Forest impact on floods due to extreme

16 rainfall and snowmelt in four Latin American environments 1: Field data analysis. Journal

17 of Hydrology, 400(3-4), 281-291.

18Beighley, R.E., Melack, J.M., Dunne, T., 2003. Impacts of California's climatic regimes and

19 coastal land use change on streaflow characteristics, Journal of the American Water

20 Resources Association, 39(6), 1419-1433.

21Berthier, E., Andrieu, H., Creutin, J.D., 2004. The role of soil in the generation of urban

22 runoff: development and evaluation of a 2D model. Journal of Hydrology, Special issue on

23 Urban Hydrology, 299(3-4), 252-266.

24Blume, T., Zehe, E., Bronstert, A., 2007. Rainfall—runoff response, event-based runoff

25 coefficients and hydrograph separation. Hydrological Sciences Journal, 52(5): 843-862.

26Booth, D.B., Hartley, D. and Jackson, R., 2002. Forest cover, impervious-surface area, and

27 the mitigation of stormwater impacts, Journal of the American Water Resources

28 Association, 38(3), 8356-845.

29Boyle, D.P., Gupta, H.V. and Sorooshian, S., 2000. Toward improved calibration of 30 hydrologica models: combining the strengths of manual and automatic methods. Water

31 Resources Research, 36(12), 3663-3674.

32Branger, F., Kermadi, S., Jacqueminet, C., Michel, K., Labbas, M., Krause, P., Braud, I.,

33 2012. Assessment of the influence of land use on the hydrology of a suburban catchment

34 using a simplified distributed modelling approach, in preparation. 
1Branger, F., Renard, B., Le Coz, J., Bonnifait, L., 2011. Assessment of uncertainty of stage-

2 discharge relations through hydraulic and bayesian approach. ICFM5: 5th International

3 Conference on Flood Management, 27-29 September 2011, Tokyo, Japan.

4Bras R.L., Perkins F.E. 1975. Effects of urbanization on catchment response. J. of Hydraulics 5 Division. Vol. 101, HY3 ,pp.451-466.

6Braud, I., 2011. Méthodologie d'analyse de tendances sur de longues séries

7 hydrométéorologiques. Fiche technique OTHU n²3, 6 pp.

8 http://www.graie.org/othu/publi3 FTech.htm

9Braud I., Chancibault K., Debionne S., Lipeme Kouyi G., Sarrazin B, Jacqueminet C., 10 Andrieu H., Béal D., Bocher E., Boutaghane H., Branger F., Breil P., Chocat B., Comby J., 11 Dehotin J., Dramais G., Furusho C., Gagnage M., Gonzalez-Sosa E., Grosprêtre L.,

12 Honegger A., Jankowfsky S., Joliveau T., Kermadi S., Lagouy M., Leblois E., Martin J.Y.,

13 Mazagol P.O., Michell K., Molines N., Mosini M.L., Puech C., Renard F., Rodriguez F.,

14 Schmitt L., Thollet F., Viallet P., 2010. The AVuPUR project (Assessing the Vulnerabiliy 15 of Peri-Urbans Rivers): experimental set up, modelling strategy and first results, 16 Proceedings of the $7^{\text {th }}$ Novatech 2010 Conference, June 28-July 12010 , Lyon, France, 10pp, 17 http://hdl.handle.net/2042/35712.

18Breil, P., Joannis, C., Raimbaud, G., Brissaud, F., Desbordes, M., 1993. Drainage des eaux 19 claires parasites par les réseaux sanitaires. De l'observation à l'élaboration d'un modèle 20 prototype. La Houille Blanche $\mathrm{N}^{\circ} 1-1993,45-57$.

21Breil, P., Radojevic, B., Chocat, B., 2010. Urban development and extreme flow regimes 22 changes, Proceedings of the 6th Friend Conference "Global change: facing risks and threats 23 to water resources”, 25-29 October 2010, Fez, Morocco, IAHS Public., 340, 314-319

24Bullock, A., 1992. The role of Dambos in determining river flow regimes in Zimbabwe. 25 Journal of Hydrology, 134(1-4), 349-372.

26Burns, D., Vitvar, T., McDonnell, J., Hassett, J., Duncan, J., Kendall, C., 2005. Effects of 27 suburban development on runoff generation in the Croton River basin, New York, USA. 28 Journal of Hydrology, 311(1-4), 266-281.

29Buytaert, W., Wyseure, G., De Bièvre, B., Deckers, J., 2005. The effect of land-use changes 30 on the hydrological behaviour of Histic Andosols in south Ecuador. Hydrological Processes, 31 19, 3985-3997.

32Chapman, T., 1991. Comment on "evaluation of automated techniques for base flow and 33 recession analyses"' by R.J. Nathan and T.A. McMahon. Water Resources Research 27 (7), $34 \quad 1783-1784$. 
1Chocat, B., P. Krebs, J. Marsalek, W. Rauch, and W. Schilling. 2001. Urban drainage

2 redefined: from stormwater removal to integrated management. Water and Science

3 Technology, 43, 61-68.

4Chormanski, J., Van de Voorde, T., De Roeck, T., Batelaan, O., Canters, F., 2008. Improving

5 distributed runoff prediction in urbanized catchments with remote sensing based estimates

6 of impervious surface cover. Sensors, 8, 910-932.

7Claessens, L., Hopkinson, C., Rastetter, E., Vallino, J., 2006. Effect of historical changes in

8 land use and climate on the water budget of an urbanizing watershed. Water Resour. Res.,

9 42, W03426.

10Cottet, M. 2005. Evolution de l'occupation du sol dans le bassin versant de l'Yzeron au cours

11 du XXème sicècle: premiers éléments pour un diagnostic hydrologique. Université Jean

12 Moulin, Lyon III, Lyon.

13Dow, C.L., 2007. Assessing regional land-use/cover influences on New Jersey Pinelands

14 streamflow through hydrograph analysis. Hydrological Processes, 21(2): 185-197.

15Elfert, S., Bormann, H., 2010. Simulated impact of past and possible future land use changes

16 on the hydrological response of the Northern German lowland [']Hunte' catchment. Journal

17 of Hydrology, 383(3-4), 245-255.

18FAO, 1998. Crop Evaporation - Guidelines for computing crop water requirements. Irrigation

19 and Drainage paper $n^{\circ} 56$, FAO, Rome.

20Furusho, C., Andrieu, H., Chancibault, K., 2011. Analysis of the hydrological functioning of

21 an Urbanizing River Basin, submitted to Hydrological Processes

22Galéa, G., Prudhomme, C., 1994. Modèles débit-durée-fréquence et conceptualisation d'un

23 hydrogramme de crue synthétique: validation sur le BVRE de Draix. Hydrologie

24 Continentale, 9(2), 139-151.

25Galéa, G., Prudhomme, C., 1997. Notions de base et concepts utiles pour la compréhension de

26 la modélisation synthétique des régimes de crue des bassins versants au sens des modèles

27 QdF. Revue des Sciences de l'Eau, 1, 83-101.

28Gnouma, R. 2006. Aide à la calibration d'un modèle hydrologique distribué au moyen d'une

29 analyse des processus hydrologiques: application au bassin versant de l'Yzeron. Institut

30 National des Sciences Appliquées de Lyon, Lyon, France, 14 Novembre 2006, 448 pp.

31 Gonzalez-Sosa, E., Braud, I., Dehotin, J., Lassabatère, L., Angulo-Jaramillo, R., Lagouy, M.,

32 Branger, F., Jacqueminet, C., Kermadi, S., Michel, K., 2010. Impact of land use on the

33 hydraulic properties of the topsoil in a small French catchment. Hydrological Processes,

34 24(17), 2382-2399. 
1Groprêtre, L., 2011. Dynamique hydro-morphologique, modélisation et gestion de petits 2 systèmes fluviaux périurbains. Recherche méthodologique appliquée au bassin de l'Yzeron.

3 Thèse de l'Université de Lyon.

4Gufstafsson, L.G., Winberg, S., Refsgaard, A., 1997. Towards a distributed physically based 5 model description of the urban aquatic environment. Water Science \& Technology, 36(8-9), 6 89-93.

7Gustard, A., Wesselink, A.J., 1993. Impact of land-use change on water-resources8 Balquhidder catchments. Journal of Hydrology, 145(3-4): 389-401.

9Hatt, B. E., T. D. Fletcher, C. J. Walsh, and S. L. Taylor. 2004. The influence of urban density 10 and drainage infrastructure on the concentrations and loads of pollutants in small streams.

11 Environmental Management, 34, 112-124.

12Jacobson, C.R., 2011. Identification and quantification of the hydrological impacts of

13 imperviousness in urban catchments: A review, Journal of Environmental Management, 14 92(6), 1438-1448.

15Jacqueminet, C., Kermadi, S., Michel, K., Chocat, B., 2011.Comment cartographier 16 l'occupation du sol et son évolution pour le suivi des phénomènes hydrologiques? Fiche 17 technique OTHU n²4, 4 pp. http://www.graie.org/othu/publi3_FTech.htm

18Jacqueminet, C., Kermadi, S., Michel, K., Béal, D., Gagnage, M., Branger, F., Jankowfsky, 19 S., Braud, I., 2012. Land cover mapping using aerial and VHR satellite images for 20 distributed hydrological modelling of periurban catchments: application to the Yzeron 21 catchment (Lyon, France), Journal of Hydrology, Periurban catchments special issue, in 22 revision.

23Jankowfsky, S., 2011 Understanding and modelling of hydrological processes in small peri24 urban catchments using an object oriented and modular distributed approach. Application to 25 the Chaudanne and Mercier sub-catchments (Yzeron catchment, France). Ph D thesis, 26 University of Grenoble, $331 \mathrm{pp}$.

27

28Jankowfsky, S., Branger, F., Braud, I., Rodriguez, F., Debionne, S., Viallet, P., 2011. 29 Influence of urban expansion on the hydrology of small catchments: development of the 30 suburban PUMMA model by coupling of urban and rural hydrological models, 12th 31 International Conference on Urban Drainage, 11-15 September 2011, Porto Alegre, Brasil, 8 32 pp. 
1Javelle, P., Grésillon, J.-M., Galéa, G., 1999. Modélisation des courbes débit-durée-fréquence

2 en crues et invariance d'échelle. Comptes Rendus de l'Académie des Sciences - Series IIA -

3 Earth and Planetary Science, 329(1), 39-44.

4Kermadi, S., Braud, I., Jacqueminet, C., Michel, K., Branger, F., 2011. Evolution de la 5 pluviométrie dans le bassin péri-urbain de l'Yzeron (Ouest Lyonnais) depuis les années

61970 et caractérisation de l'imperméabilisation, XXIVème Colloque de l'Association

7 Internationale de Climatologie, 6-11 Septembre 2011, Rovereto (Italie), 6 pp.

8 http://www.climato.be/aic/colloques.html

9

10Kermadi, S., Renard, F., Braud, I., Jacqueminet, C., Michel, K., Branger, F., 2012.

11 Occupation du sol et pluviométrie dans un bassin versant péri-urbain soumis aux

12 inondations : Yzeron (Ouest Lyonnais), 14 pp, Climatologie, in revision

13Kliment, Z., Matoušková, M., 2009. Runoff Changes in the Šumava Mountains (Black Forest)

14 and the Foothill Regions: Extent of Influence by Human Impact and Climate Change. Water

15 Resources Management, 23(9), 1813-1834.

16Lafont, M., A. Vivier, S. Nogueira, P. Namour, and P. Breil. 2006. Surface and hyporheic

17 oligochaete assemblages in a Friench suburban stream. Hydrobiologia, 564, 183-193.

18Lang, M., Ouarda, T.B.M.J., Bobee, B. 1999. Towards operational guidelines for over-

19 threshold modelling, Journal of Hydrology, 225(3-4), 103-117.

20Lang, M., Renard, B., Sauquet, E., Bois, P., Dupeyrat, A., Laurent, C., Mestre, O., Niel, H.,

21 Neppel, L., Gailhard, J., 2006. A national study on trends and variations of French floods

22 and droughts, Climate Variability and Change-Hydrological Impacts (Proceedings of the

23 Fifth FRIEND World Conference held at Havana, Cuba, November 2006), IAHS Publ. 308,

$242006,514-519$.

25Madsen, H., 2000. Automatic calibration of a conceptual rainfall-runoff model using multiple

26 objectives. Journal of Hydrology, 235, 276-288.

27Mann. H. B , Whitney.D. R., 1947. On a test of whether one of two random variables is 28 stochastically larger than the other. Ann. Math. Statist, 18(1), 50-60.

29Marsalek, J., Jiméénez-Cisneros, B.E., Karamouz, M., Malmquist, P.A., Gldenfum, J. and 30 Chocat, B., 2007. Urban water processes and interactions. UNESCO IHP-VI program,

31 UNESCO, Paris, 239 pp.

32Matteo, M., T. Randhir, and D. Bloniarz. 2006. Watershed-scale impacts of forest buffers on 33 water quality and runoff in urbanizing environment. Journal of the American Water 34 Resources Association, 132, 144-152. 
1Meierdiercks, K.L., Smith, J.A., Baeck, M.L., Miller, A.J., 2010. Analyses of Urban Drainage

2 Network Structure and its Impact on Hydrologic Response1. JAWRA Journal of the

3 American Water Resources Association, 46(5), 932-943.

4Meija, A.I., Moglen, G.E., 2010. Spatial distribution of imperviousness and the space-time

5 variability of rainfall, runoff generation, and routing. Water Resources research, 46:

6 W07509, doi:10.1029/2009WR008568.

7Ostrowski, M.W., 2000. Anthropogenic impacts on the formation of flash floods and

8 measures for their compensation, in Flood Issues in Contemporary Water Management,

9 Proceedings of the NATO Advanced Research Workshop on Coping with Floods, Maleno-

10 vice, Czech Republic, Mai 2000, NATO Science Series, 2. Environmental Security - Vol.

11 71, Kluwer Academic Publishers, ISBN 0-7923-6452-X

12Ostrowski, M., Bras,R.L. 2000 Simulation of the effects of urbanization on catchments

13 response. MS Thesis, MIT, Cambridge, MA.

14OTHU, 2011. http://www.graie.org/othu/. Consulted on 2010/09/16.

15Ott, B., Uhlenbrook, S., 2004. Quantifying the impact of land-use changes at the event and 16 seasonal time scale using a process-oriented catchment model. Hydrology and Earth System 17 Sciences, 8(1), 62-78.

18Paul M.J. \& Meyer J.L., 2001. Streams in the urban landscape. Annu. Rev. Ecol. Syst., 32, $19 \quad 333-365$

20Pettitt, A.N., 1979. A non parametric approach to the change point problem, Applied 21 Statistics, 28, 126-135.

22Praskievicz, S., Chang, H., 2009. A review of hydrological modelling of basin-scale climate 23 change and urban development impacts. Progress in Physical Geography, 33(5), 650-671.

24Prigiobbe, V., Guilianelli, M., 2009. Quantification of sewer system infiltration using d180 25 hydrograph separation, Water Scienc \& Technology, 60(3), 727-735.

26Quintana-Segui, P., Le Moigne, P., Durand, Y., Martin, E., Habets, F., Baillon, M., Canellas, 27 C., Franchisteguy, L. and Morel, S., 2008. Analysis of near-surface atmospheric variables:

28 validation of the SAFRAN analysis over France. Journal of Applied Meteorology and 29 Climatology, 47, 92-107.

30Radojevic, B., 2002. Méthode d'évaluation de l'influence urbaine sur le régime des crues d'un 31 bassin versant de $130 \mathrm{~km} 2$, Institut National des Sciences Appliquées de Lyon, Lyon, 252 32 pp. 
1Radojevic, B., Breil, P. and Chocat, B., 2010. Assessing impact of global change on flood 2 regimes. International Journal of Climate Change Strategies and Management, 2(2), 1673179 .

4Randhir, T., 2003. Watershed-scale effects of urbanization on sediment export: assessement 5 and policy, Water Resources Research, 39(6), 1-13.

6Renard, B., Lang, M., Bois, P., Dupeyrat, A., Mestre, O., Niel, H., Gailhard, J., Laurent, C., 7 Neppel, L. and Sauquet, E., 2006. Evolution des extrêmes hydrométriques en France à partir 8 de données observées. La Houille Blanche - Revue Internationale de l'eau, 6, 48-54.

9Richter, B.D., Baumgartner, J. V. , Powell, J., Braun, D.P., 1996. A method for assessing 10 hydrologic alteration within ecosystems. Conservation Biology 10(4), 1163-1174.

11Richter, B.D., Baumgartner, J.V., Wigington, R., Braun, D.P., 1997. How much water does a 12 river need? Freshwater Biology 37(1), 1-249.

13Richter, B.D., Mathews, R., Harrison, D.L., Wigington, R., 2003. Ecologically sustainable 14 water management: Managing river flows for ecological integrity. Ecological Applications 15 13(1),206-224.

16Rodriguez, F., Andrieu, H., Morena, F., 2008. A distributed hydrological model for urbanized 17 areas - Model development and application to case studies. Journal of Hydrology, 351(3-4), $18 \quad 268-287$.

19Sarrasin, B., 2012. Approches spatiales pour décrire le réseau de drainage et suivre sa 20 dynamique de fonctionnement en milieu rural dans une perspective d'aide à la modélisation 21 hydrologique Ecole doctorale Terre, Univers, Environnement. l'Institut National 22 Polytechnique de Grenoble.

23Sauquet, E., Gottschalk, L. and Krasovskaia, I., 2008. Estimating mean monthly runoff at 24 ungauged locations: an application to France. Hydrology Research, 39(5-6), 403-423.

25Sauquet, E., Krasovskaia, I., Leblois, E., 2000. Mapping mean monthly runoff pattern using 26 EOF analysis. Hydrology and Earth System Sciences, 4(1): 79-93.

27Sauquet, E., Leblois, E., 2001. Discharge analysis and runoff mapping applied to the 28 evaluation of model performance. Physics and Chemistry of the Earth, 26(5), 473-478.

29Schmitt L, Grosprêtre L, Breil P, Lafont M, Vivier A, Perrin JF, Namour P, Jezequel C, 30 Valette L, Valin K, Cordier R, Cottet M. 2008. Préconisations de gestion physique de petits 31 hydrosystèmes périurbains : l'exemple du bassin de l'Yzeron (France). In. Actes du 32 Colloque « La gestion physique des cours d'eau : bilan d'une décennie d'ingénierie 33 écologique », Verniers G, Petit F (eds), Namur, 10-12 oct. 2007, Groupe Interuniversitaire 34 de Recherches en Ecologie Appliquée, Laboratoire d'Hydrographie et de Géomorphologie 
1 Fluviatile, Direction des Cours d'Eau Non Navigables, Direction Générale des Ressources

2 Naturelles et de l'Environnement - Ministère de Région wallonne : 177-186.

3Sheeder, S.A., Ross, J.D., Carlson, T.N., 2002. Dual urban and rural hydrograph signals in

4 three small watersheds, Journal of the American Water Resources Association, 38(4), 1027 -

51040.

6SIRA, 2011. Sol Info Rhône-Alpes, sira@rhone-alpes.chambagri.fr - http://www.rhone-

7 alpes.chambagri.fr/sira/. Consulted on 2010/09/16.

8Stedinger, J.R., Vogel, R.M., Foufoula-Georjiou, E., 1992. Frequency analysis of extreme 9 events, Chapter18. In Handbook of hydrology. Ed.: Maidment D.R. Mc Graw-Hill, Inc. 10 New-York.

11Tallaksen, L.M., Van Lane, H.A.J., 2004. Hydrological drought: processes and estimation 12 methods for streamflow and groundwater. Developments in water science 48, Elsevier,

13 Amsterdam, The Netherlands, 579 pp.

14Tetzlaff, D., Grottker, M., Leibundgut, C., 2005. Hydrological criteria to assess changes of 15 flow dynamic in urban impacted catchments. Physics and Chemistry of the Earth, Parts $16 \mathrm{~A} / \mathrm{B} / \mathrm{C}, 30(6-7), 426-431$.

17Tong, S.T.Y., 1990. The hydrologic effects of urban land use: a case study of the Little Miami 18 River basin. Landscape and Urban Planning, 19, 99-105.

19Vázquez, R.F. and Feyen, J., 2010. Rainfall-runoff modelling of a rocky catchment with 20 limited data availability: Defining prediction limits. Journal of Hydrology, 387(1-2), 12821140.

22Vázquez, R.F., Willems, P. and Feyen, J., 2008. Improving the predictions of a MIKE SHE 23 catchment-scale application by using a multi-criteria approach. Hydrological Processes, 24 22(13), 2159-2179.

25Vidal, J.P., Martin, E., Franchisteguy, L., Baillon, M., Soubeyroux, J.M., 2010. A 50-year 26 high-resolution atmospheric reanalysis over France with the SAFRAN system International 27 Journal of Climatology, 30(11), 1627-1644.

28Wagener, T., Boyle, D.P., Lees, M.J., Weater, H.S., Gupta, H.V. and Sorroshian, S., 2001. A 29 framework for development and application of hydrological models. Hydrology and Earth 30 System Sciences, 5(1), 13-26.

31Walsh, C.J., Fletcher, T.D., Ladson, A.R., 2005. Stream restoration in urban catchments 32 through redesigning stormwater systemes: looking to the catchment to save the stream.

33 Journal of the North American Benthological Society, 24(3), 690-705. 
1Wang, G., Liu, J., Kubota, J., Chen, L., 2007. Effects of land-use changes on hydrological 2 processes in the middle basin of the Heihe River, northwest China. Hydrological Processes, 3 21(10), 1370-1382.

4Willems, P., 2009. A time series tool to support the multi-criteria performance evaluation of 5 rainfall-runoff models. Environmental Modelling \& Software, 24(3), 311-321. 


\section{List of figures}

\section{2}

3Figure 1: Map of the DTM (25m resolution) of the Yzeron catchment with location of the 4rainfall gauges and streamflow gauges. For the gauges used in the study the corresponding 5 sub-catchments are delineated in yellow. The location of roads and built areas is also shown 6in grey.

7Figure 2: Maps of land use of the Yzeron catchment in (a) 1970; (b) 1990; (c) 2008. The 8original maps were obtained by manual digitalization of aerial photographs by Jacqueminet et 9al. (2011), UMR EVS, 2010. They were reclassified in 3 classes: wooded areas (broad leaved 10and coniferous forests, moors), agricultural areas (crops, pastures, orchards, gardens) and 11 artificialized areas (urban parcels including gardens and parks, roads, parkings).

12

13Figure 3: Zoom of the available gauging stations on the Chaudanne river, close to the Sewer 14Overflow Device (SOD1). It shows the location of the gauging stations in the stream, the 15SOD1, the combined sewer system (CSS). The approximate location of SOD2 and La 16Léchère gauging stations is also provided.

17Figure 4: Land use of the various study catchments. Three classes are presented: wooded, 18agricultural and artificialized areas (see Figure 2 caption).

19Figure 5: (a) Illustration of the sampling strategy used in the QdF method for various duration $20 d$ and $d_{2}$. (b) Determination of the flood hydrograph shape. Light grey lines are individual 21 floods normalised by their maximum value $Q_{\max }$. The thick black line is the median of all the 22curves. $\theta$ is the flood characteristic duration corresponding to $Q / Q_{\max }=0.5$ in the median 23hydrograph.

24Figure 6: Scheme illustrating the methodology retained for the decomposition of combined 25sewer system (CSS) discharge between waster water discharge (WW), clear groundwater 26infiltration (GW) and runoff (RW). SOD refers to the contribution of a SOD is present.

28Figure 7: Average monthly specific discharge of the Craponne, Taffignon, Pollionnay, 29Upstream_SOD1, La Léchère stations. For the La Léchère station, two graphs are provided 30 corresponding to the minimum $\left(2.9 \mathrm{~km}^{2}\right)$ and maximum $\left(4.1 \mathrm{~km}^{2}\right)$ catchment area.

\section{1}

32Figure 8: (a) Flow duration curve (FDC) for the daily specific discharge of the Taffignon, 33Craponne, Pollionnay, Upstream_SOD1, La_Léchère (area $2.9 \mathrm{~km}^{2}$ ) stations. (b) FDC of the 
1sewer discharge (CSS) and its components: rainwater runoff (RW+SOD1), infiltration of 2groundwater (GW), waste water (WW).

3Figure 9: (a) Normalised median of the flood hydrographs for the Taffignon, Craponne, 4Pollionnay, Upstream_SOD1, La_Léchère, CSS_RW+SOD1 stations. (b) Normalised median 5 of the flood hydrographs for the Craponne gauge and its "Rural" and "SOD" components. (c) 6Normalised median of the flood hydrographs for the La Léchère gauge and its "Rural" and 7“SOD2” components.

8Figure 10: Specific discharge from the POT analysis of the Taffignon, Craponne, Pollionnay, 9Upstream_SOD1, La_Léchère (with surface catchment 2.9 and $4.1 \mathrm{~km} 2$ ) stations for the 10duration $d=0$ (peak discharge) and $d=12 \mathrm{~h}$. The analysis was performed extracting an average 11 of four flood events per year. The x-axis provides the empirical return period of each event.

12Figure 11: Result of the filtering of the SOD2 discharge from the La Léchère gauge discharge 13time series for the 01-06 July 2007 period. The discharge of the upstream SOD1 is also 14shown.

15Figure 12: Top: fraction of the total monthly discharge (\%) coming from the SODs for the 16Craponne and La Léchère stations. Bottom: fraction of zero daily discharge (\%) for the 17Craponne and La Léchère stations and their filtered Rural and SOD components.

18Figure 13: Discharge from the POT analysis of the Craponne (bottom) and La Léchère (top) 19stations and their rural and SOD components for the duration $d=0$ (peak discharge) and $d=3 \mathrm{~h}$. 20The analysis was performed extracting an average of four flood events per year. The $\mathrm{x}$-axis 21 provides the empirical return period of each event.

22Figure 14: Partition of the monthly sewer discharge volume data into the runoff component 23(grey) and the groundwater infiltration (black) for the 2001-2010 period. The monthly rainfall 24is shown at the top of the graph. The date format in the $\mathrm{x}$-axis is yy-mm where 01 is 2001 for 25 instance. 
1Table 1: Indicators derived from discharge time series analysis found in the literature, and 2associated references. We distinguished studies based on model simulations and data analysis. 3In bold, we highlight references dealing with catchment urbanization. With a star, the study 4uses paired catchments

\begin{tabular}{|c|c|c|}
\hline Analysed indicators & Model simulation & Data analysis \\
\hline \multicolumn{3}{|l|}{ Hydrological regime } \\
\hline Mean annual runoff, runoff coefficient & $\begin{array}{llll}\text { Ashagrie } & \text { et } & \text { al. } & (2006), \\
\text { Beighley } & \text { et } & \text { al. } & \mathbf{( 2 0 0 3 ) ,}\end{array}$ & $\begin{array}{l}\text { *Arrigoni et al. (2010), Bullock } \\
\text { (1992), Wang et al. (2007) }\end{array}$ \\
\hline & Praskievicz and Chang (2009), & \\
\hline Seasonal runoff & Praskievicz and Chang (2009) & Richter et al. (1996) \\
\hline Quantiles & & *Arrigoni et al. (2010) \\
\hline Flow duration curve & Gustard and Wesselink (1993) & $\begin{array}{l}\text { *Bathurst et al. (2011), Wang et } \\
\text { al. (2007) }\end{array}$ \\
\hline Water balance components & $\begin{array}{l}\text { Claessens et al. (2006), Elfert } \\
\text { and Bormann (2010) }\end{array}$ & \\
\hline
\end{tabular}

\begin{tabular}{|c|c|c|}
\hline High flows & & \multirow{4}{*}{$\begin{array}{l}\text { *Arrigoni et al. (2010), } \\
\text { *Bathurst et al. (2011), Bullock } \\
\text { (1992),Wang et al. (2007), } \\
\text { Richter et al. (1996) } \\
\text { Tong (1990), }\end{array}$} \\
\hline $\begin{array}{l}\text { Value and/or date of annual max peak } \\
\text { discharge or max annual discharge other } \\
\text { several durations }\end{array}$ & $\begin{array}{l}\text { Ashagrie et al. (2006), } \\
\text { Beighley et al. (2003), Burns } \\
\text { et al. (2005), Praskievicz and } \\
\text { Chang (2009) }\end{array}$ & \\
\hline Peak over threshold (POT) & $\begin{array}{l}\text { Vazquez et al. (2008), } \\
\text { Willems (2009), Vazquez and } \\
\text { Feyen (2010) }\end{array}$ & \\
\hline QdF (discharge-duration-frequency) & $\begin{array}{l}\text { Sauquet and Leblois (2001), } \\
\text { Radojevic et al. (2010) }\end{array}$ & \\
\hline
\end{tabular}

\begin{tabular}{ll}
\hline Low flows & \\
\hline $\begin{array}{l}\text { Value and/or date of annual min discharge } \\
\text { (or minimum over a period of several days) }\end{array}$ & $\begin{array}{l}\text { Ashagrie et al. (2006), Burns } \\
\text { et al. (2005), Praskievicz and } \\
\text { Chang (2009) } \\
\text { POT for low flow }\end{array}$ \\
& Vazquez et al. (2008), \\
& Willems (2009), Vazquez and \\
&
\end{tabular}

Low flow frequency, $\mathrm{Q}_{95 \%}$

Gustard and Wesselink (1993)

*Arrigoni et al. (2010), Richter et al. (1996)

Bullock (1992), *Dow (2007), Wang et al. (2007)

Bullock (1992)

\begin{tabular}{|c|c|c|}
\hline \multicolumn{3}{|l|}{ Indicators based on hydrographs analyses } \\
\hline $\begin{array}{l}\text { Indicators derived from events analysis: } \\
\text { runoff coefficient, recession curves }\end{array}$ & $\begin{array}{l}\text { Chormanski et al. (2008), } \\
\text { Meierdiercks et al. (2010), } \\
\text { Ott and Uhlenbrook (2004) }\end{array}$ & *Buytaert et al. (2004) \\
\hline Flow components based on flow separation & $\begin{array}{l}\text { Vazquez et al. (2008), } \\
\text { Willems (2009), Vazquez and } \\
\text { Feyen (2010) }\end{array}$ & \\
\hline $\begin{array}{l}\text { Number and/or duration of discharge } \\
\text { exceeding thresholds } \\
\text { Number and/or duration of rising and } \\
\text { falling rate of discharge exceeding } \\
\text { thresholds }\end{array}$ & & $\begin{array}{l}\text { *Archer (2007), Richter et al. } \\
(1996) \\
\text { Archer et al. (2010), Richter et } \\
\text { al. (1996), Tetzlaff et al. (2005) }\end{array}$ \\
\hline \multicolumn{3}{|l|}{ Results of statistical analyses } \\
\hline $\begin{array}{l}\text { Statistical comparison of sub-periods } \\
\text { Trend detection } \\
\text { Regression with landscape characteristics }\end{array}$ & $\begin{array}{l}\text { Radojevic et al. (2010) } \\
\text { Claessens et al. (2006) }\end{array}$ & $\begin{array}{l}\text { Tong (1990), Wang et al. (2007) } \\
\text { Kliment and Matoušková (2009) } \\
\text { *Arrigoni et al. (2010), } \\
\text { *Dow(2007), Tetzlaff et al. } \\
\text { (2005), Wang et al. (2007) }\end{array}$ \\
\hline
\end{tabular}


1Table 2: Characteristics of the gauged sub-catchments

\begin{tabular}{|c|c|c|c|}
\hline River & $\begin{array}{l}\text { Name of the gauging } \\
\text { station }\end{array}$ & $\begin{array}{l}\text { Catchment area } \\
\left(\mathrm{km}^{2}\right)\end{array}$ & Data availability \\
\hline Yzeron & Taffignon & 129.00 & 1988/09/16 - present \\
\hline Yzeron & Craponne & 48.00 & $1969 / 10 / 27$ - present \\
\hline Mercier & Pollionnay & 6.77 & 1997/01/14 - present \\
\hline Chaudanne & Upstream_SOD1 & 2.19 & $\begin{array}{l}\text { 1997/06/21 - 2001/07/24; } \\
\text { 2005/01/01 - present }\end{array}$ \\
\hline Chaudanne & La_Léchère & 2.9 to $4.1(*)$ & 2005/01/01 - present \\
\hline Chaudanne & SOD1 & $\approx 0.16$ & 2001/06/26 - present \\
\hline Chaudanne & CSS & $\approx 0.16$ & $2000 / 11 / 15$ - present \\
\hline
\end{tabular}

$2\left(^{*}\right)$ The La Léchère area is minimum $\left(2.9 \mathrm{~km}^{2}\right)$ under dry conditions, and can reach $4.1 \mathrm{~km}^{2}$ 3 when all the SODs are activated (Jankowfsky, 2011) 
1 Table 3: Time series derived by the filtering methods

2

\begin{tabular}{|c|c|c|c|c|}
\hline River & $\begin{array}{l}\text { Name of the time } \\
\text { series }\end{array}$ & $\begin{array}{l}\text { Discharge } \\
\text { component }\end{array}$ & Method of derivation & $\begin{array}{l}\text { Catchment } \\
\text { area }\left(\mathrm{km}^{2}\right)\end{array}$ \\
\hline Yzeron & Craponne_SOD & $\begin{array}{l}\text { Upstream } \\
\text { contribution }\end{array}$ & 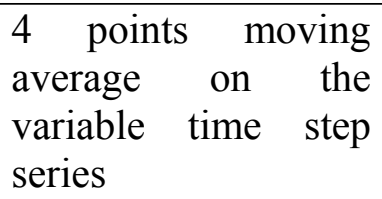 & $\approx 4.5$ \\
\hline Yzeron & Craponne_Rural & $\begin{array}{l}\text { "Rural" discharge } \\
\text { without the } \\
\text { upstream SOD }\end{array}$ & $\begin{array}{l}4 \text { points moving } \\
\text { average on the } \\
\text { variable time step } \\
\text { series }\end{array}$ & 48 \\
\hline Chaudanne & La_Léchère_SOD2 & $\begin{array}{l}\text { Upstream SOD2 } \\
\text { contribution }\end{array}$ & $\begin{array}{l}4 \text { points moving } \\
\text { average on the } \\
\text { variable time step } \\
\text { series }\end{array}$ & $\approx 1.1$ \\
\hline Chaudanne & La_Léchère_Rural & $\begin{array}{l}\text { "Rural" discharge } \\
\text { without the } \\
\text { upstream SOD2 }\end{array}$ & $\begin{array}{l}4 \text { points moving } \\
\text { average on the } \\
\text { variable time step } \\
\text { series }\end{array}$ & 2.9 \\
\hline Chaudanne & CSS_RW+SOD1 & Rainwater runoff & $\begin{array}{l}\text { Filtering of the } 6 \mathrm{mn} \\
\text { Chaudanne_CSS } \\
\text { series }\end{array}$ & $\approx 0.16$ \\
\hline Chaudanne & CSS_GW & $\begin{array}{l}\text { Groundwater } \\
\text { infiltration into the } \\
\text { CSS }\end{array}$ & $\begin{array}{l}\text { Filtering of the } 6 \mathrm{mn} \\
\text { Chaudanne_CSS } \\
\text { series }\end{array}$ & - \\
\hline Chaudanne & CSS_WW & Waste water & $\begin{array}{l}\text { Filtering of the } 6 \mathrm{mn} \\
\text { Chaudanne_CSS } \\
\text { series }\end{array}$ & - \\
\hline
\end{tabular}


1Table 4: Mean annual discharge $Q_{A}\left(\mathrm{~m}^{3} \mathrm{~s}^{-1}\right)$ and corresponding specific discharge $q_{A}\left(1 \mathrm{~s}^{-1} \mathrm{~km}^{-}\right.$ $2^{2}$ ), $50 \%$ quantile of the flow duration curves, $Q_{50 \%}$; frequency of zero daily discharge and BFI; 3 maximum daily discharge $Q_{\max }\left(\mathrm{m}^{3} \mathrm{~s}^{-1}\right)$, and corresponding specific discharge $q_{\max }\left(1 \mathrm{~s}^{-1} \mathrm{~km}^{-2}\right)$; 4 characteristic flood duration for an extraction of 4 floods per year, $\theta(\mathrm{h})$, and duration, $d(\mathrm{~h})$, 5retained for the QdF analysis. Specific discharges are not provided for the SODs and 6CSS_RW+SOD components, due to the large uncertainty on their drained areas. For the La 7Léchère station, figures in parenthesis correspond to a $4.1 \mathrm{~km}^{2}$ catchment area.

\begin{tabular}{|c|c|c|c|c|c|c|c|c|c|}
\hline Series & $Q_{A}$ & $q_{A}$ & $Q_{50 \%}$ & $\begin{array}{c}\% \text { of zero } \\
\text { daily } \\
\text { discharge }\end{array}$ & BFI & $Q_{\max }$ & $q_{\max }$ & $\theta$ & $d$ \\
\hline & $\mathrm{m}^{3} \mathrm{~s}^{-1}$ & $\begin{array}{l}1 \mathrm{~s}^{-1} \\
\mathrm{~km}^{2}\end{array}$ & $\mathrm{~m}^{3} \mathrm{~s}^{-1}$ & - & - & $\mathrm{m}^{3} \mathrm{~s}^{-1}$ & $\begin{array}{l}1 \mathrm{~s}^{-1} \\
\mathrm{~km}^{2}\end{array}$ & $\mathrm{~h}$ & $\mathrm{~h}$ \\
\hline \multicolumn{10}{|c|}{ Observed time series } \\
\hline Taffignon & 0.664 & 5.15 & 0.275 & 5.44 & 0.388 & 46.25 & 358.5 & 6 & 12 \\
\hline Craponne & 0.332 & 6.92 & 0.169 & 0.25 & 0.486 & 20.94 & 436.2 & 7 & 12 \\
\hline Pollionnay & 0.045 & 6.65 & 0.129 & 13.96 & 0.336 & 5.95 & 878.9 & 3 & 12 \\
\hline Upstream_SOD1 & 0.012 & 5.55 & 0.0028 & 31.25 & 0.307 & 0.67 & 305.9 & 10 & 12 \\
\hline La_Léchère & 0.019 & $\begin{array}{l}6.55 \\
(4.63)\end{array}$ & 0.0069 & 11.15 & 0.260 & 1.58 & $\begin{array}{c}544.8 \\
(385.4)\end{array}$ & 1 & 4 \\
\hline SOD1 & 0.00027 & - & 0.000 & 87.00 & - & 0.06 & - & 1 & 1 \\
\hline CSS & 0.00545 & - & 0.0039 & 0.24 & - & 0.13 & - & - & - \\
\hline \multicolumn{10}{|c|}{ Derived series using the filtering methods } \\
\hline Craponne_Rural & 0.289 & 6.02 & 0153 & 0.53 & 0.536 & 14.79 & 308.1 & 16 & 12 \\
\hline Craponne_SOD & 0.045 & - & 0.003 & 34.31 & - & 6.21 & - & 3 & 1 \\
\hline La_Léchère_Rural & 0.018 & 6.20 & 0.0056 & 15.96 & 0.269 & 1.50 & 517.2 & 1 & 4 \\
\hline La_Léchère_SOD2 & 0.001 & - & 0.0002 & 22.86 & - & 0.08 & - & 1 & 1 \\
\hline CSS_RW+SODD 1 & 0.002 & - & 0.0012 & 9.90 & - & 0.13 & - & 1 & 1 \\
\hline CSS_GW & 0.002 & - & 0.0015 & 48.33 & - & 0.03 & - & - & - \\
\hline CSS DW & 0.002 & - & 0.0017 & 0.00 & - & 0.002 & - & - & - \\
\hline
\end{tabular}


1Table 5: Decomposition of the discharge into base flow, inter flow and quick flow (in $\%$ of 2 the total volume) for the 5 gauged catchments. The values of the constant of the exponential 3recession model, $k$ (days) and the $w$ parameters are also given.

4

\begin{tabular}{lcccccc}
\hline Gauging station & $\begin{array}{c}\text { Exponential } \\
\text { parameter } k \text { for } \\
\text { the base flow } \\
\text { extraction (days) }\end{array}$ & $\begin{array}{c}\text { Exponential } \\
\text { parameter } k \text { for } \\
\text { the inter flow } \\
\text { extraction (days) }\end{array}$ & $\begin{array}{c}w(-) \\
\text { parameter }\end{array}$ & $\begin{array}{c}\% \\
\text { base } \\
\text { flow }\end{array}$ & $\begin{array}{c}\% \\
\text { inter } \\
\text { flow }\end{array}$ & $\begin{array}{c}\% \\
\text { quick } \\
\text { flow }\end{array}$ \\
\hline Taffignon & 35 & 12 & 0.25 & 39.3 & 23.1 & 37.6 \\
Craponne & 28 & 7 & 0.20 & 49.8 & 24.6 & 25.6 \\
Pollionnay & 5 & 3 & 0.28 & 34.6 & 21.9 & 43.5 \\
Upstream_SOD1 & 5 & 3 & 0.32 & 30.2 & 20.8 & 49.0 \\
La_Léchère & 3.75 & 1.5 & 0.35 & 26.3 & 19.2 & 54.5 \\
\hline
\end{tabular}


1Table 6: Results of statistical tests applied to the Craponne daily discharge time series. The $p$ 2 values of the Mann-Kendall trend tests are provided in the first line and the direction of the 3 trend ( + for an increase, - for a decrease) are given in parenthesis when significant. The 4second line contains the p-value of the Pettitt test and the date of the most probable rupture is 5 given in parenthesis when significant. The $p$-value are followed with $(*)$ when the test is 6 significant at the $10 \%$ level, $(* *)$ at the $5 \%$ level and $(* * *)$ at the $1 \%$ level. The POT analysis 7 is applied on the $Q C X_{d}$ data (maximum discharge continuously exceeded during the duration $8 d$ ) extracted with an average of two floods per year on the variable time step discharge time 9 series.

10

Indicator calculated using the daily discharge at Craponne from 1970-2010

\begin{tabular}{|c|c|}
\hline \multirow{2}{*}{$\begin{array}{l}\text { BFI (calculated using the Tallaksen et al., } \\
2004 \text { algorithm) }\end{array}$} & $0.12(-)$ \\
\hline & 0.17 \\
\hline \multirow[t]{2}{*}{ \% base flow (from WETSPRO) } & $0.02 * *(-)$ \\
\hline & 0.13 \\
\hline \multirow[t]{2}{*}{$\%$ inter flow (from WETSPRO) } & $0.006 * * *(-)$ \\
\hline & 0.11 \\
\hline \multirow[t]{2}{*}{ \% quick flow (from WETSPRO) } & $0.001 * * *(+)$ \\
\hline & $0.02 * *(1988)$ \\
\hline \multirow[t]{2}{*}{ Max annual discharge } & 0.21 \\
\hline & 0.63 \\
\hline \multirow[t]{2}{*}{ POT $Q C X d=0$ (maximum peak discharge) } & 0.35 \\
\hline & 1.05 \\
\hline \multirow[t]{2}{*}{ POT $Q C X$ duration $d=1 \mathrm{~h} 30$} & $0.04 * *(+)$ \\
\hline & 0.17 \\
\hline \multirow[t]{2}{*}{ POT $Q C X$ duration $d=3 \mathrm{~h}$} & $0.06 *(+)$ \\
\hline & 0.13 \\
\hline \multirow[t]{2}{*}{ POT $Q C X$ duration $d=6 \mathrm{~h}$} & $0.07 *(+)$ \\
\hline & $0.08 *(1979)$ \\
\hline \multirow[t]{2}{*}{ POT $Q C X$ duration $d=12 \mathrm{~h}$} & $0.06 *(+)$ \\
\hline & 0.21 \\
\hline \multirow[t]{2}{*}{ POT $Q C X$ duration $d=36 \mathrm{~h}$} & $0.07 *(+)$ \\
\hline & $0.07 *(1977)$ \\
\hline
\end{tabular}


Author-produced version of the article published in Journal of Hydrology, 2013, 485, 5-23 The original publication is available at http://www.sciencedirect.com/ doi:10.1016/j.jhydrol.2012.04.049

\section{${ }_{2}^{1 \text { Figure } 1}$}

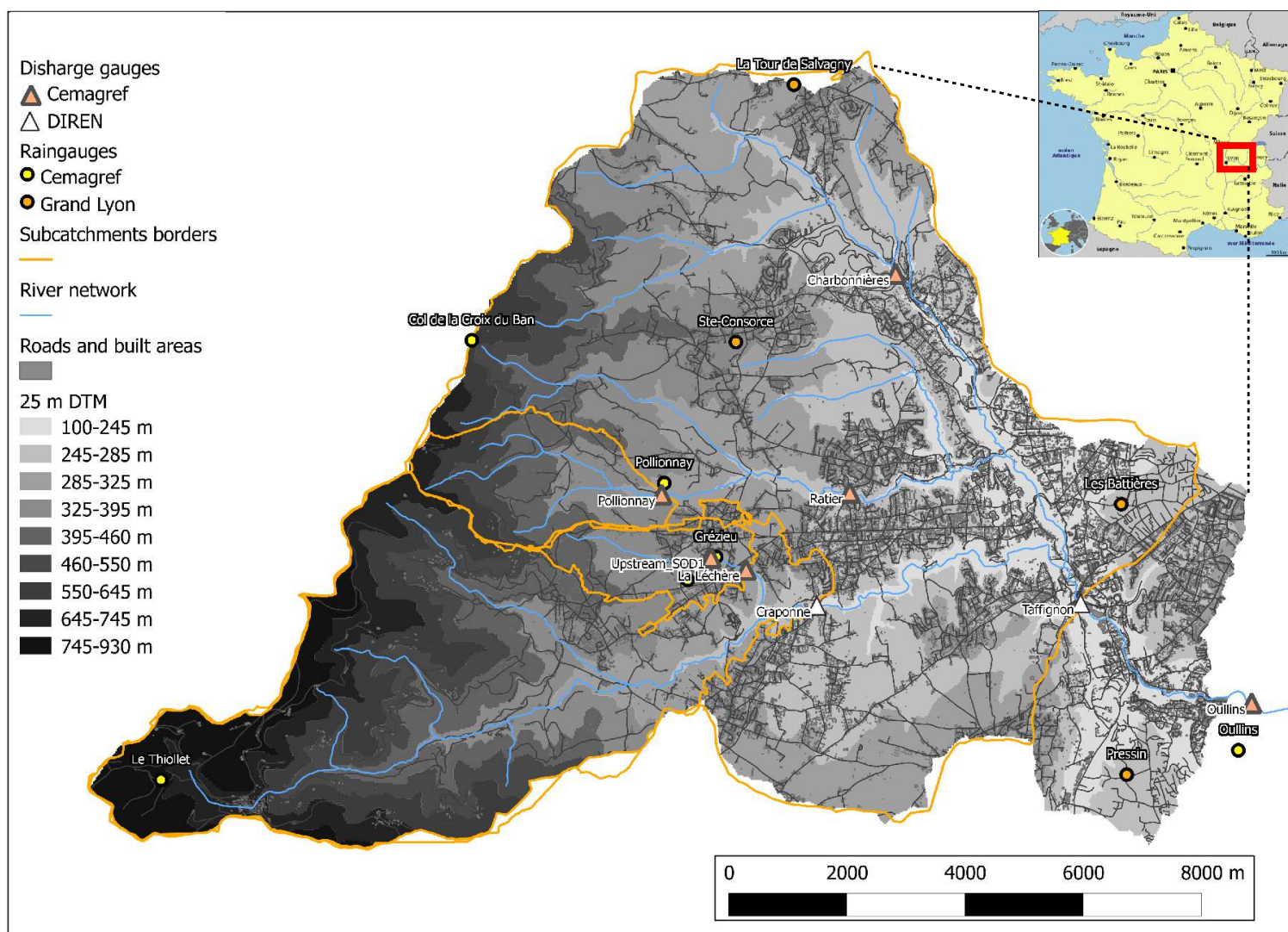


1 Figure 2

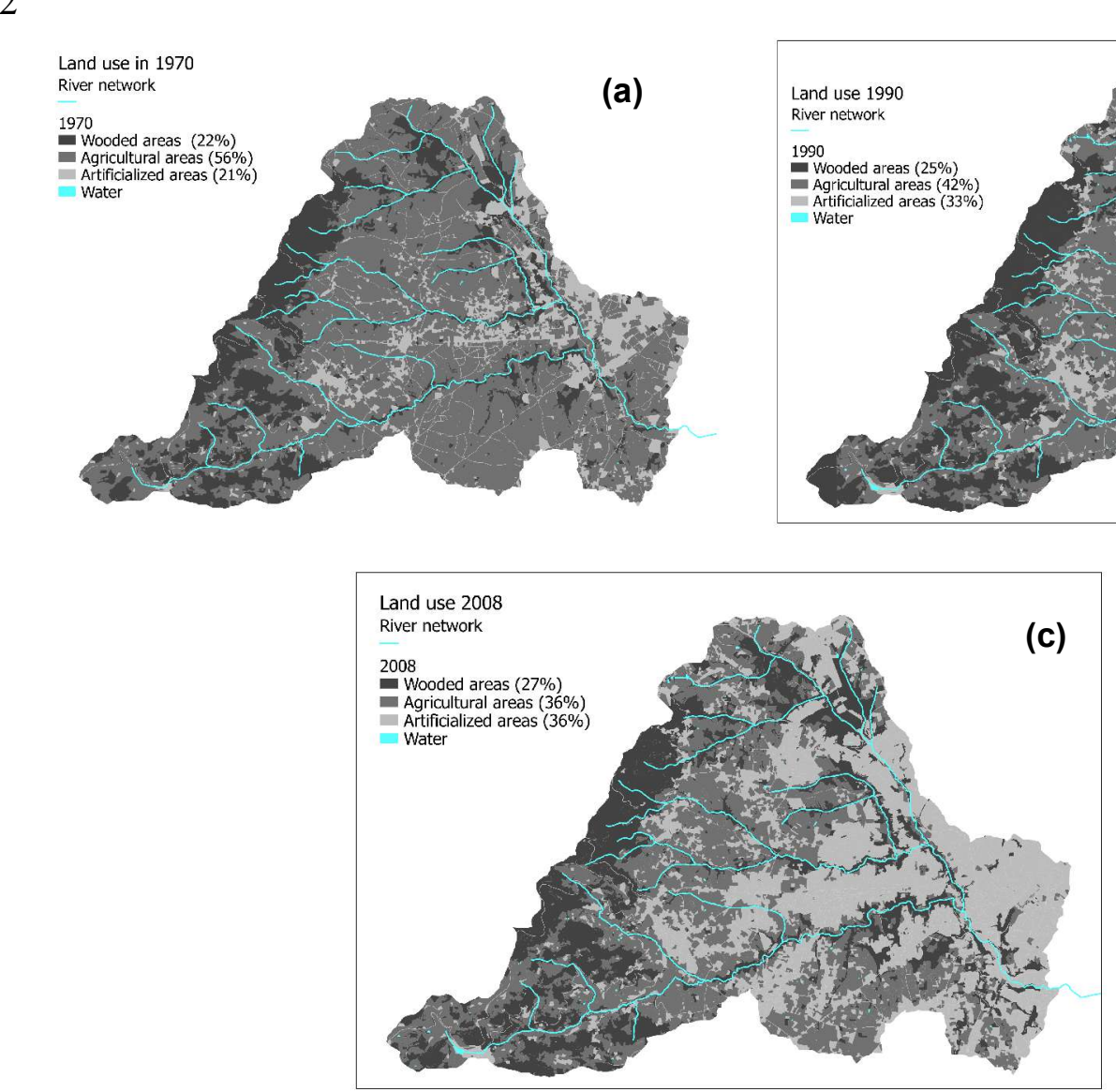


1Figure 3

2

Combined Sewer

Rainta

System
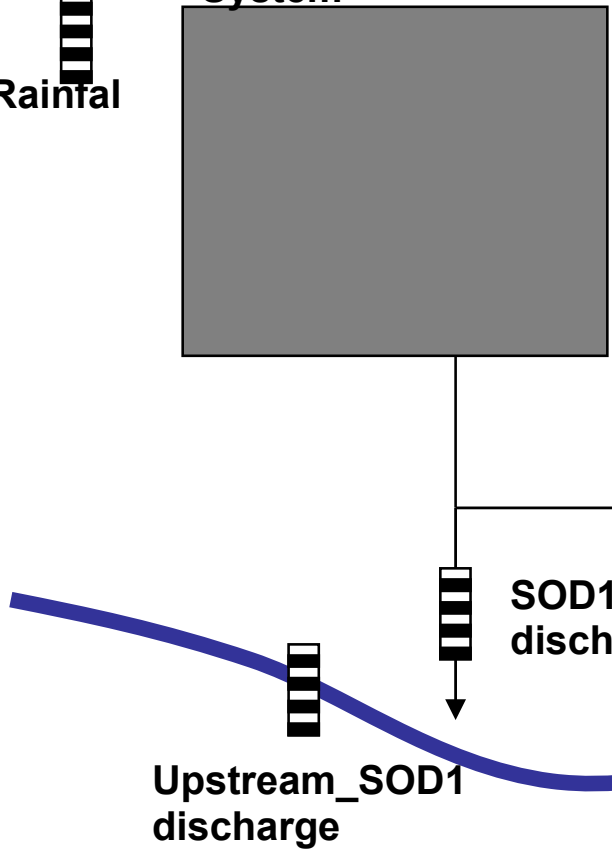

CSS

discharge

Towards WWTP

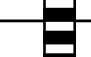

SOD1

discharge

La Léchère

discharge 
1Figure 4

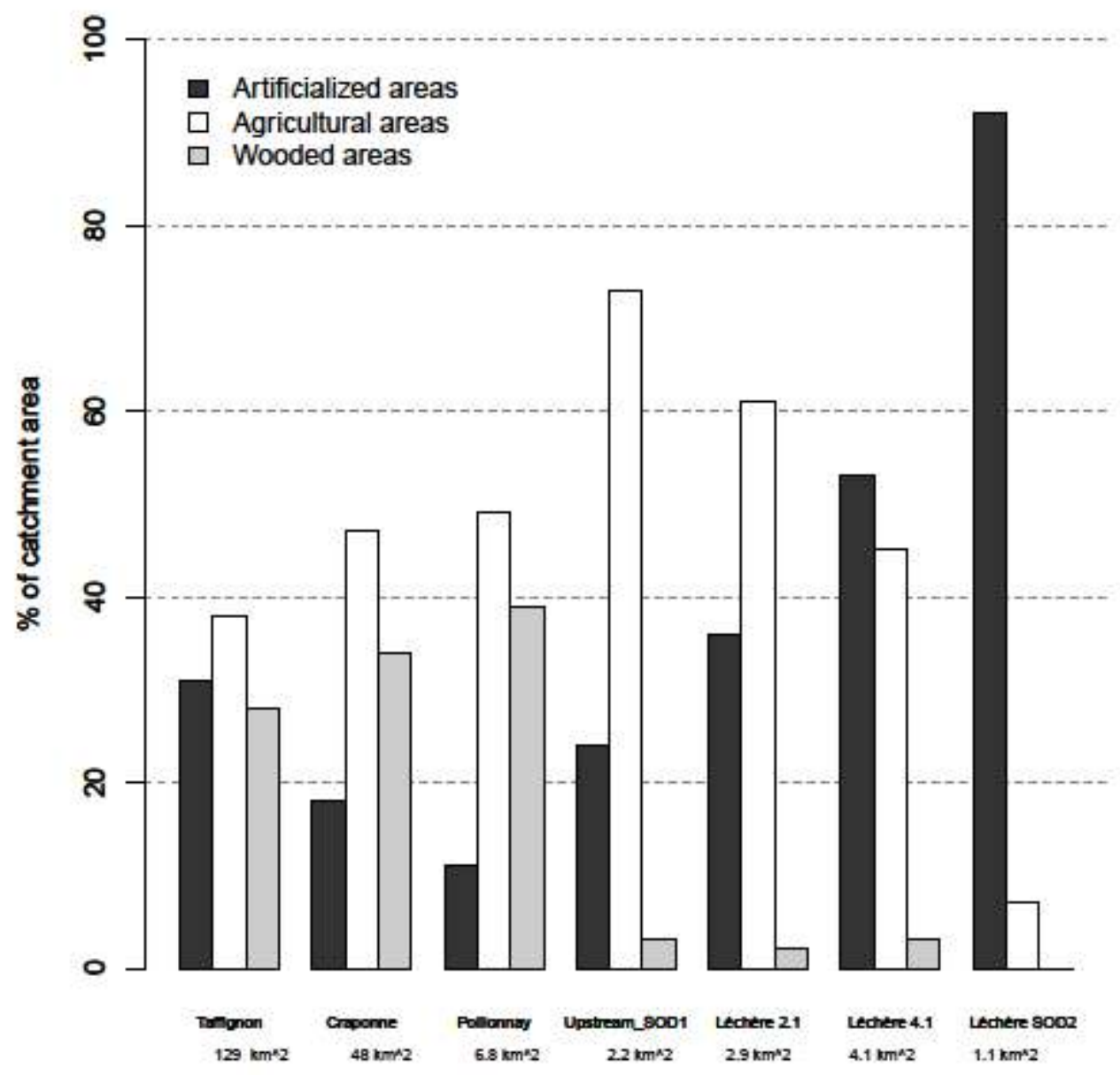


1 Figure 5

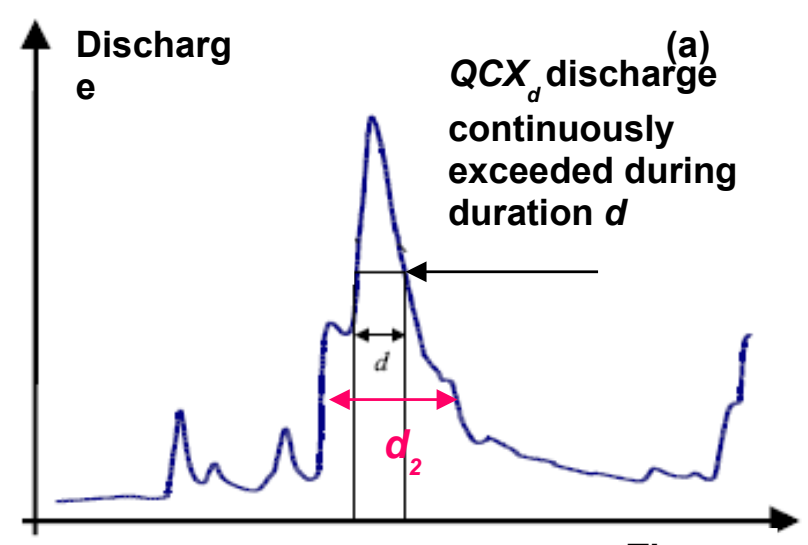

Time b)

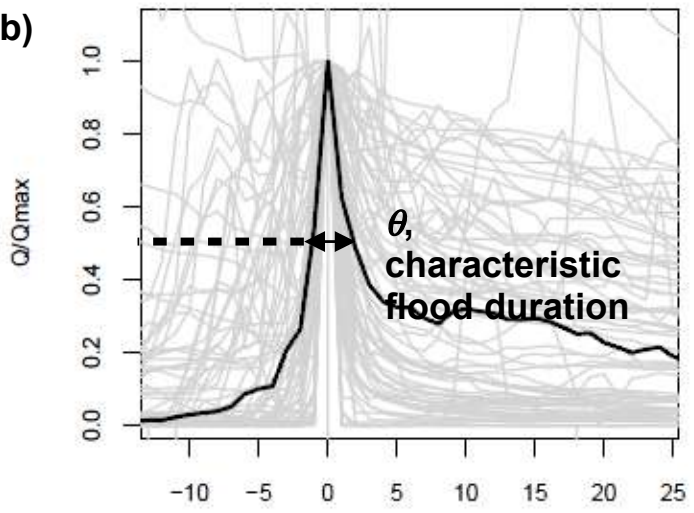

Time (hour) 
1 Figure 6

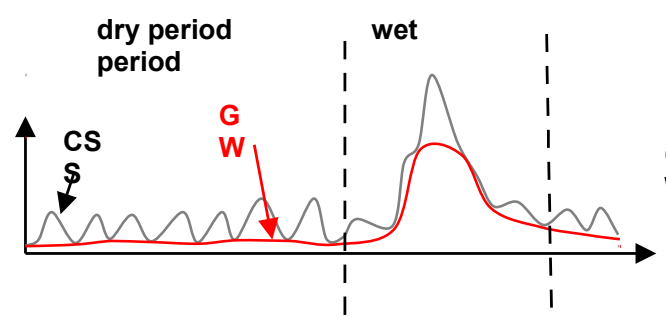

Step 1a: Filtering of parasite clear ${ }^{\prime}$ groundwater (GW) from the combined sewer system (CSS) discharge

css

GW

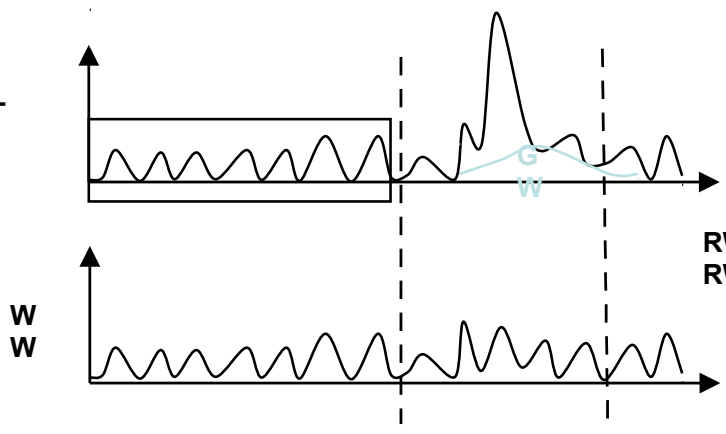

Step 1b: Extraction of the dry period data and building of an average weekly waste water WW cycle css-

WW

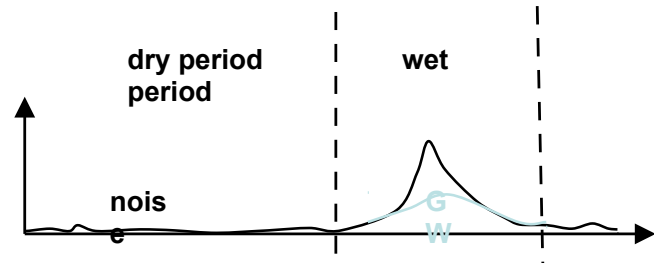

Step 2: Filtering of the CSS - WW time series to derive the runoff + parasite clear groundwater discharges $(\mathrm{RW}+$ GW). New filtering to separate runoff RW and GW.

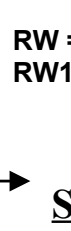

Step 3: If a SOD exists, total runoff is given by the RW +SOD discharge 
1Figure 7
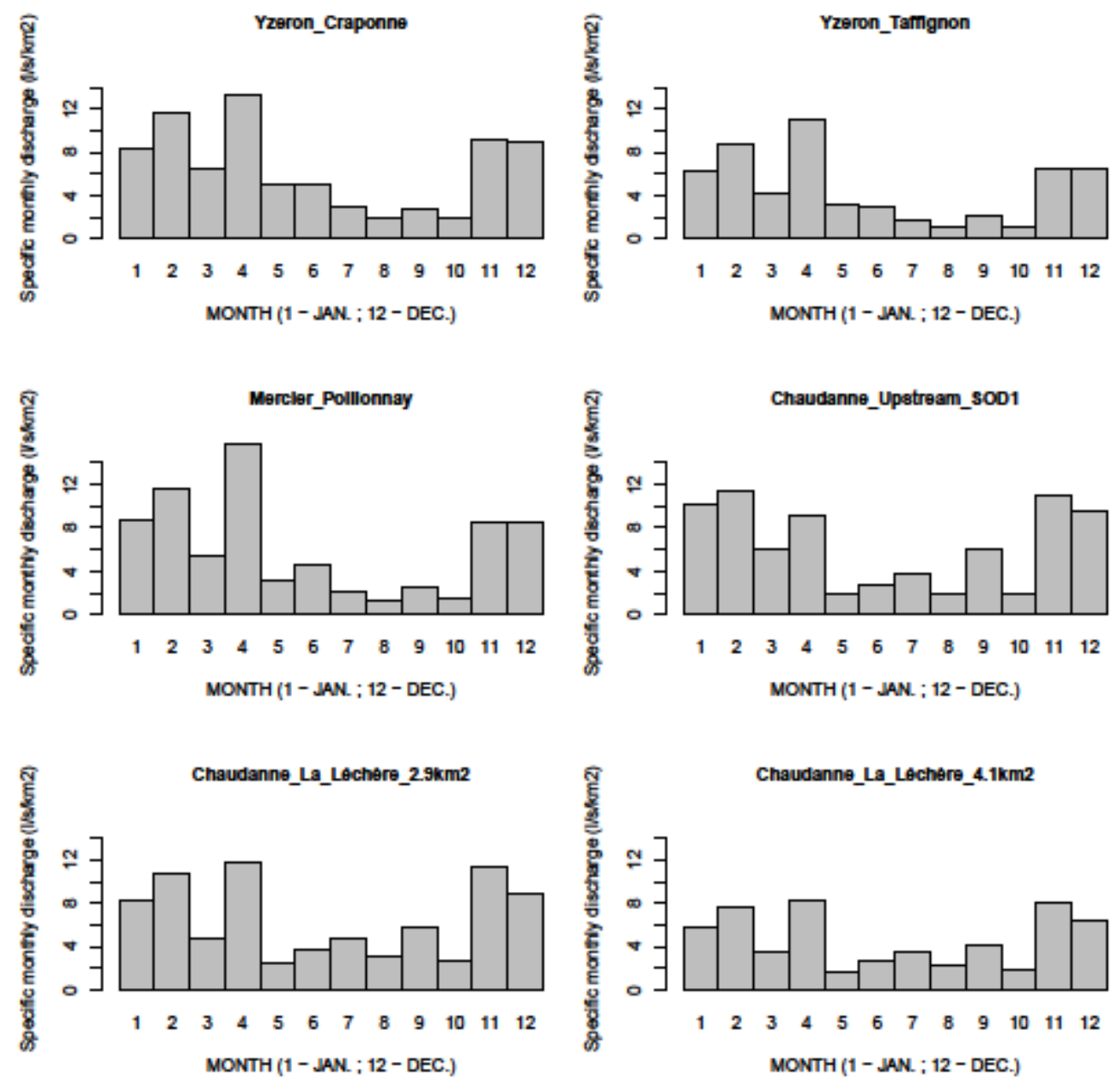
1Figure 8
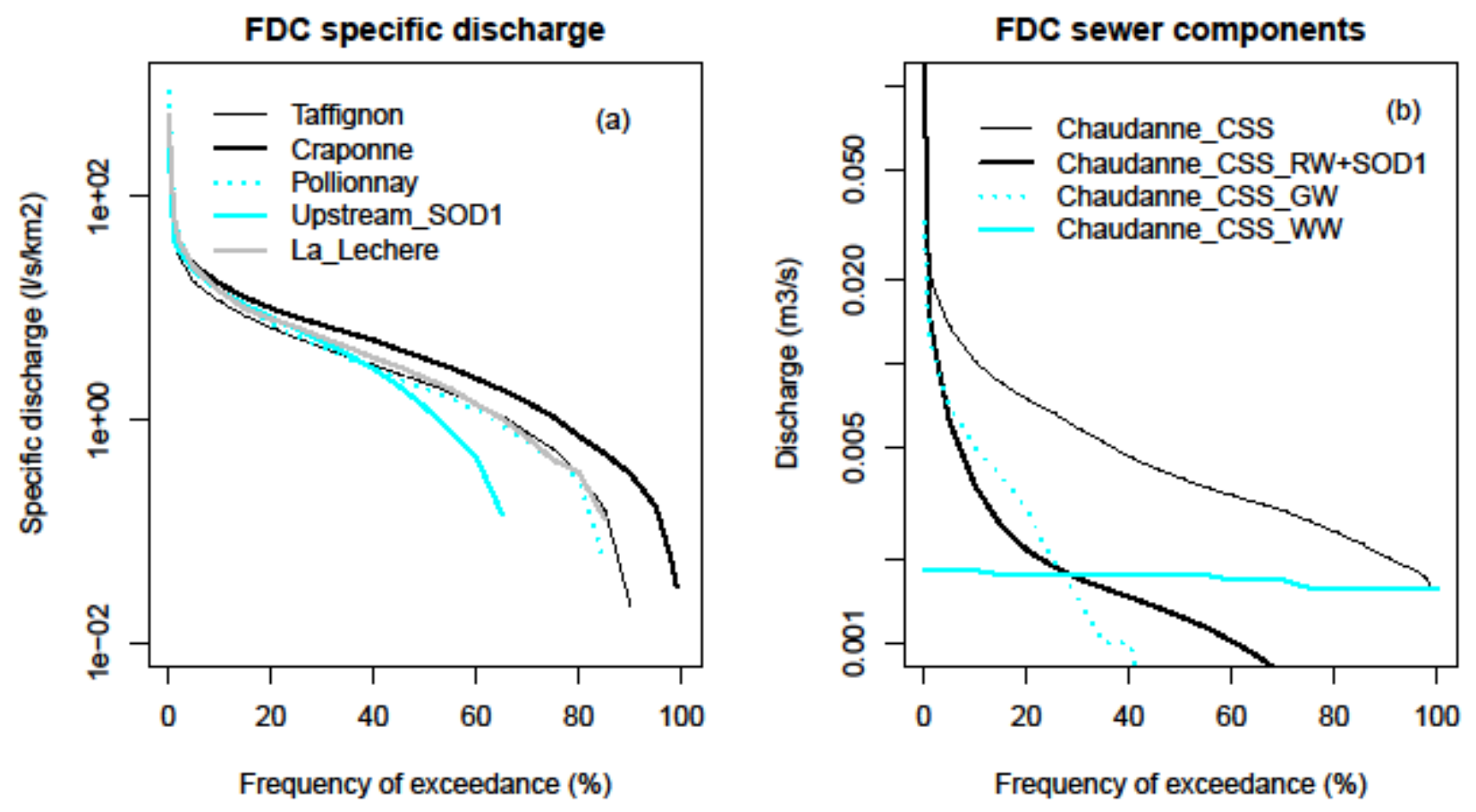
1Figure 9
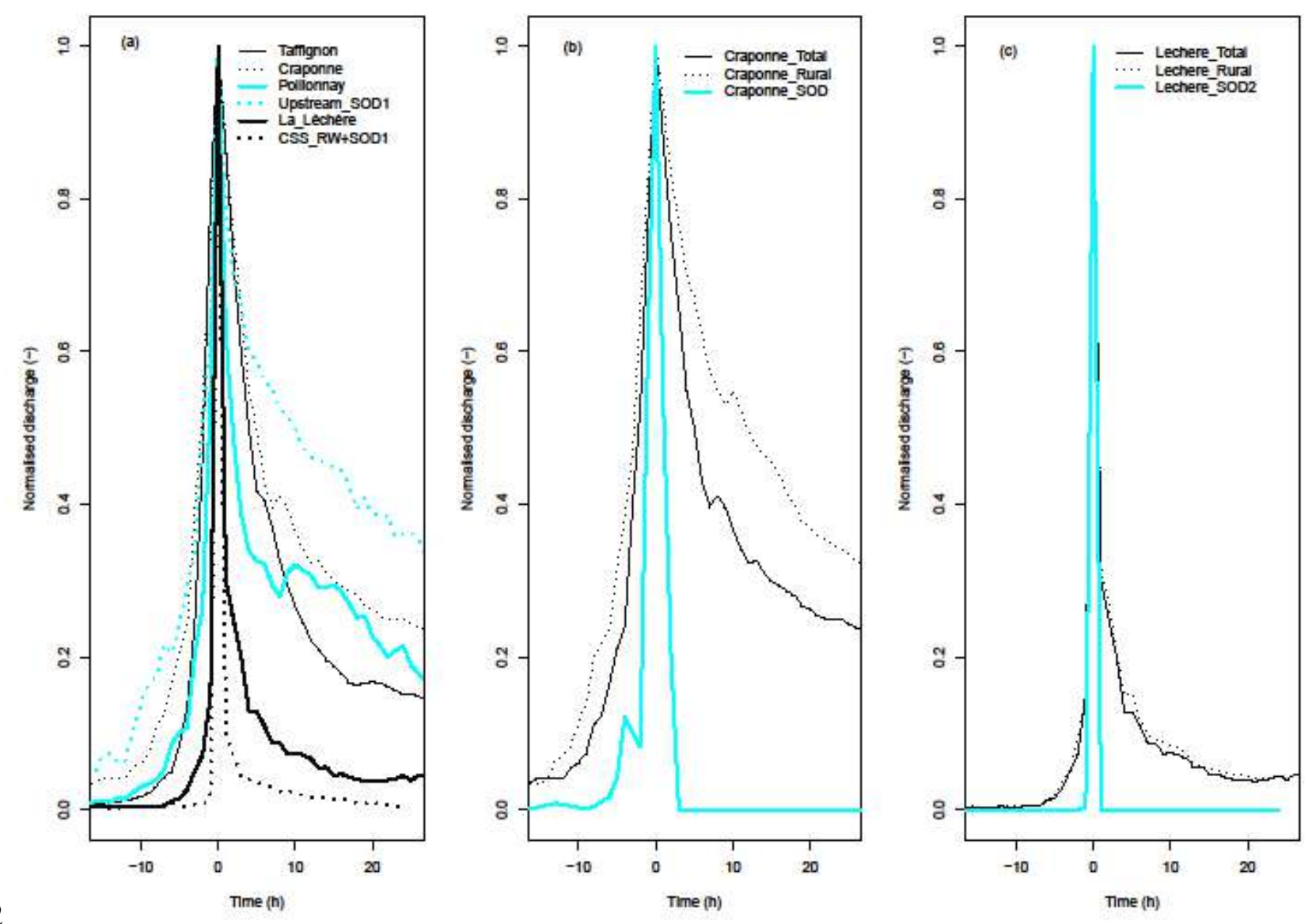
1Figure 10

d=0. Maximum peak discharge

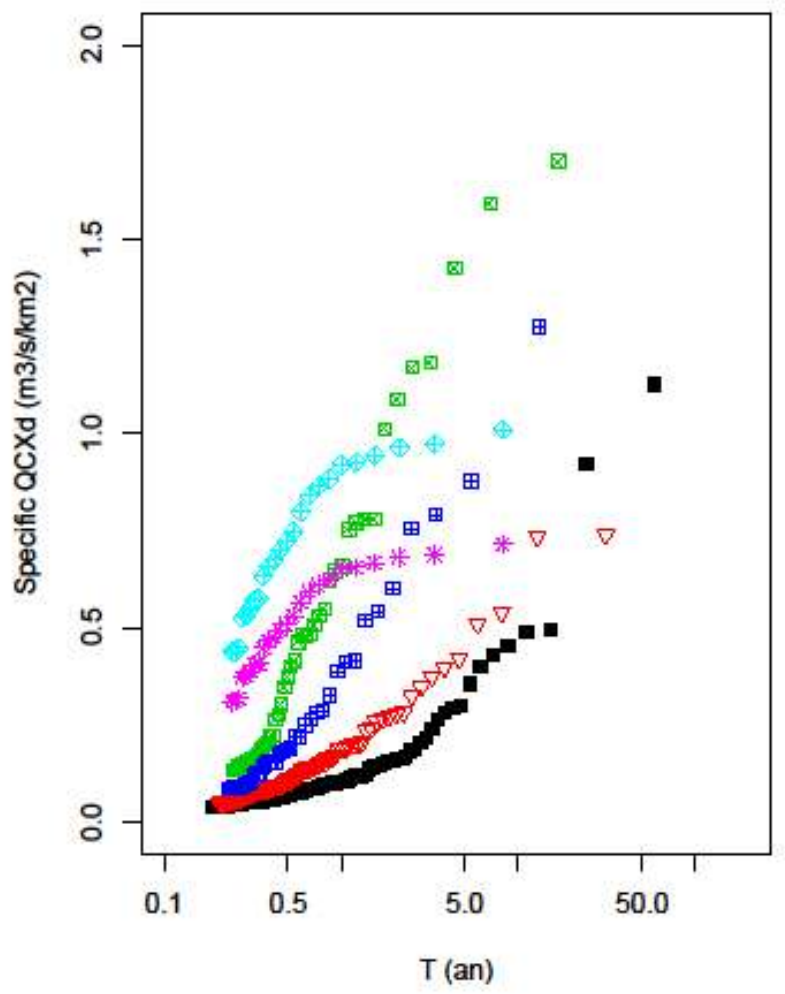

$d=12 h$

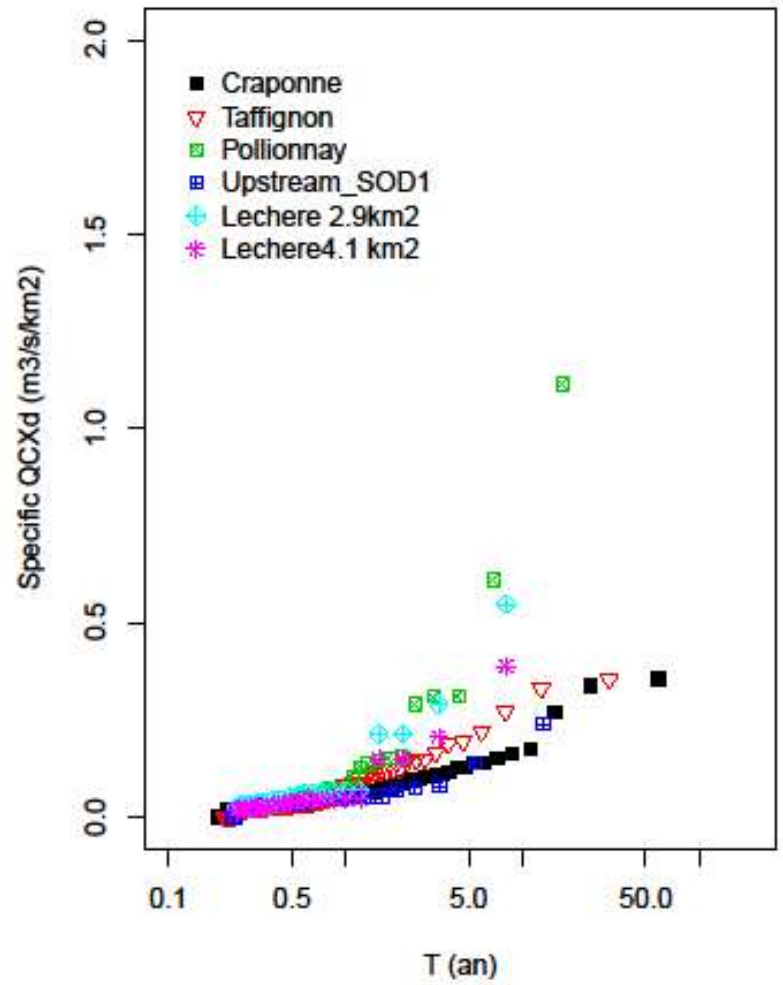


1Figure 11

Filtering of SOD2 discharge, La Lechere 01-06 July 2007

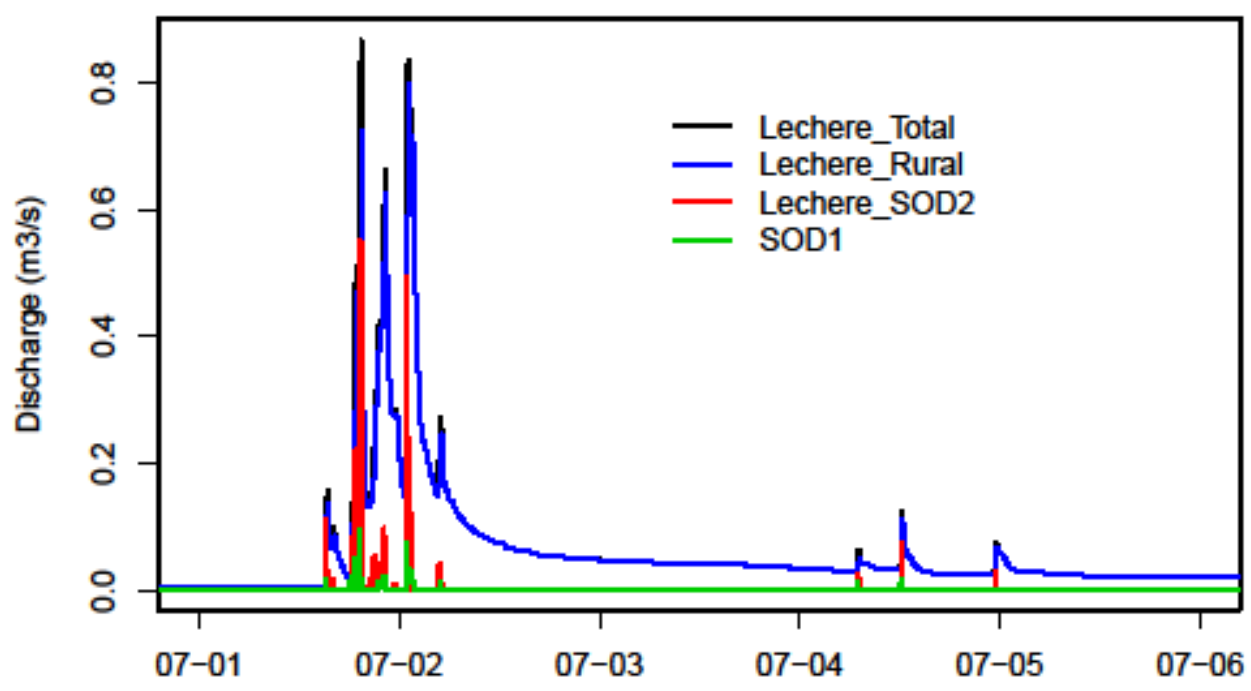

2 
1Figure 12

Craponne_soD
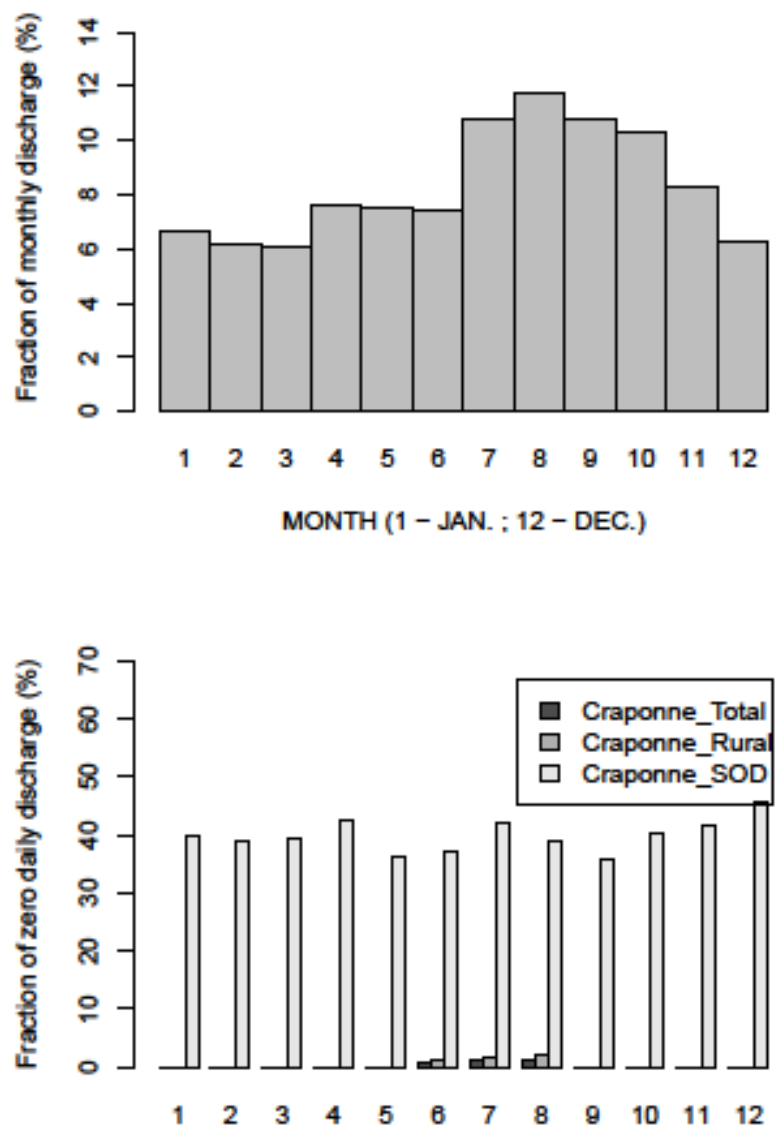

2
La_Léchère_SOD2
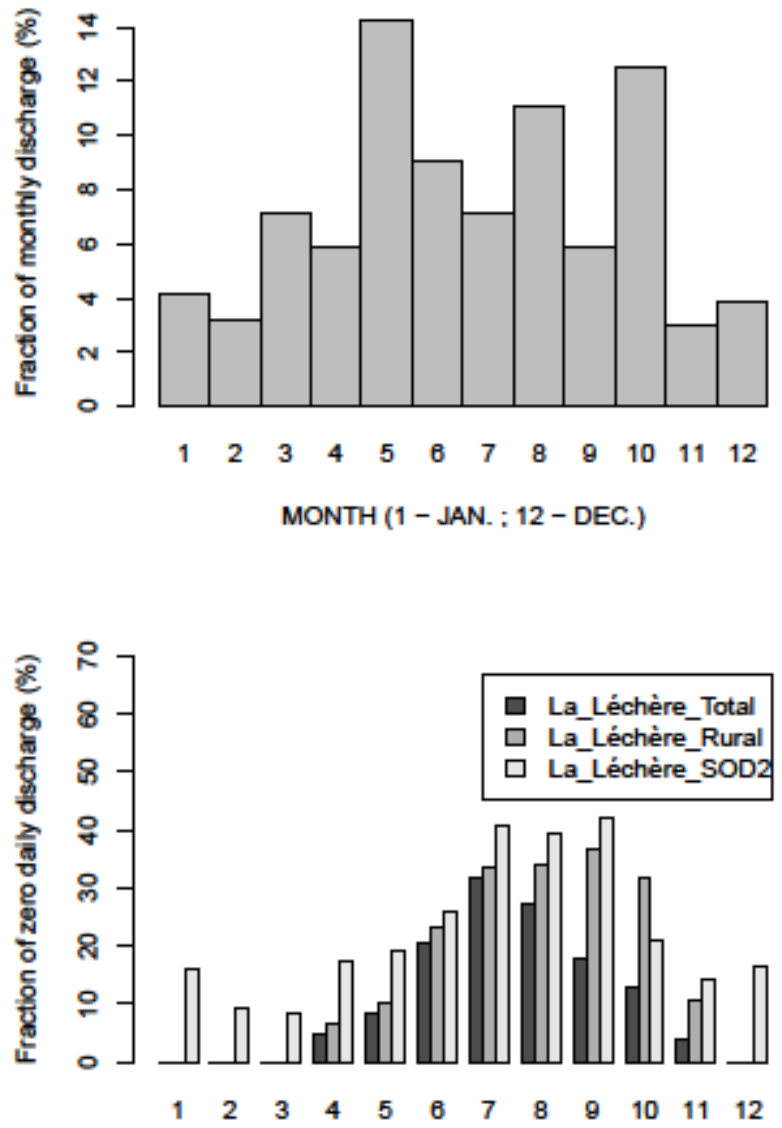

MONTH (1 - JAN. : 12 - DEC.) 
1Figure 13
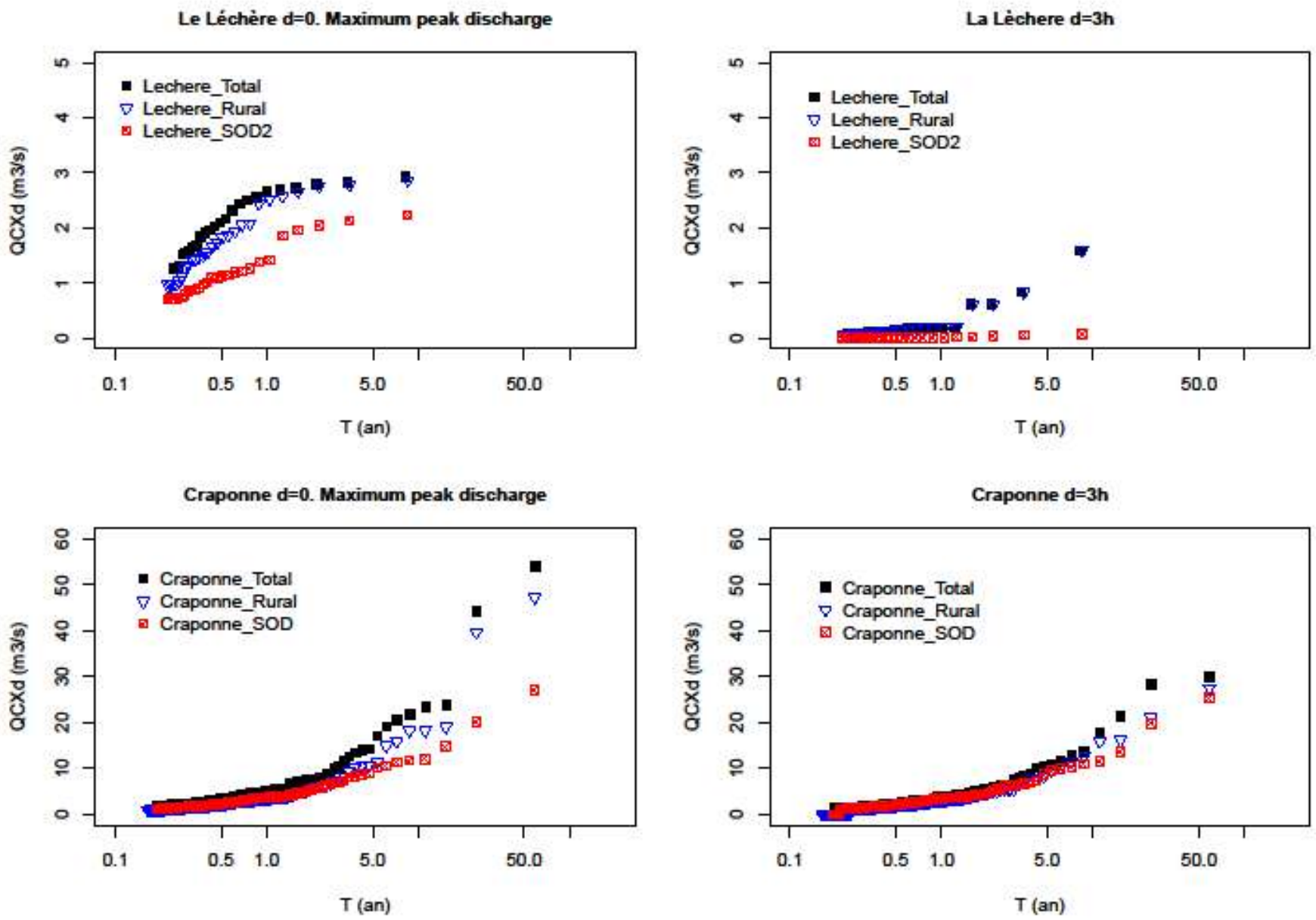
1Figure 14

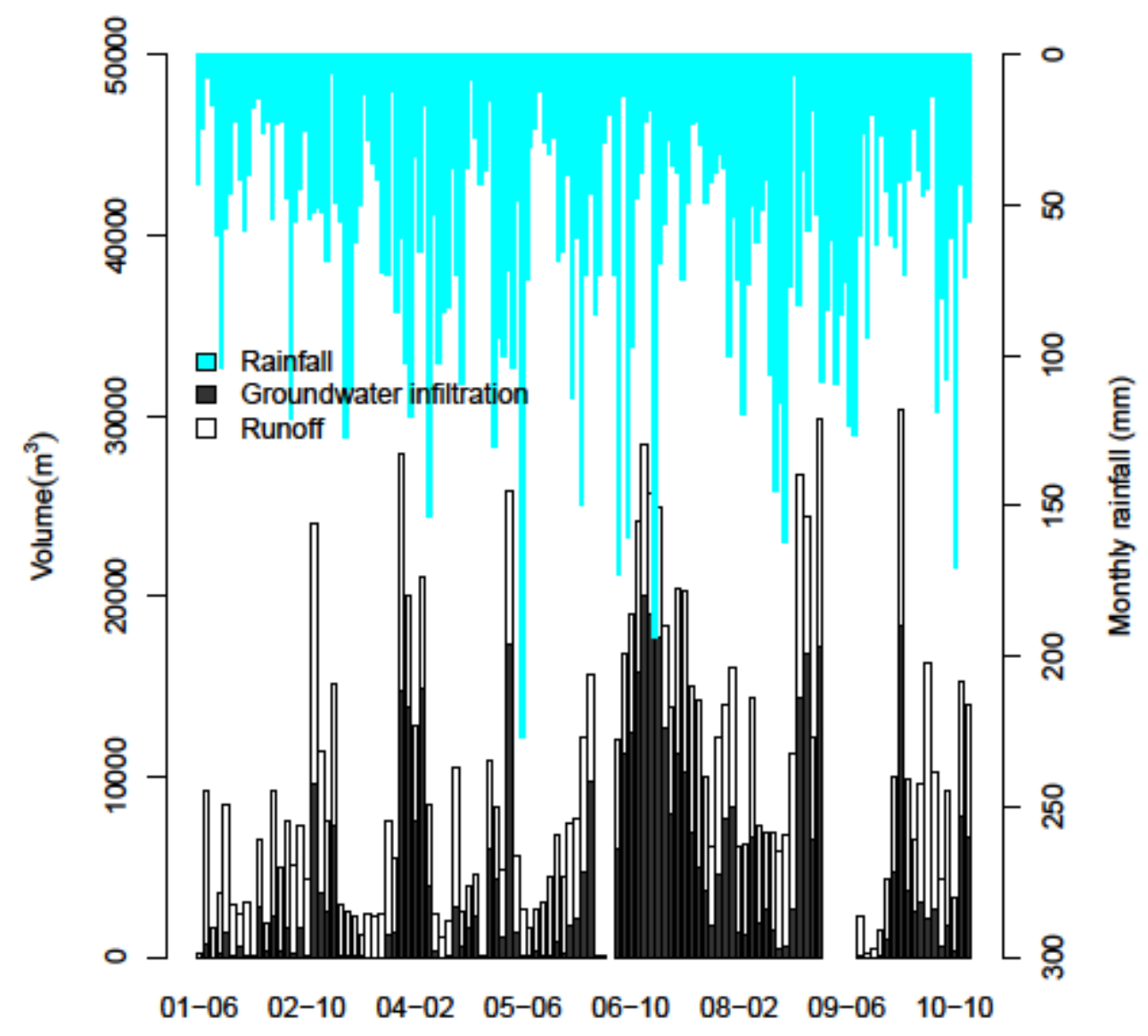

